\title{
CIVIL AERONAUTICS BOARD POLICY: AN EVALUATION
}

SPIRALING operating deficits ${ }^{1}$ and current governmental investigations 2 have focused attention on the plight of commercial aviation, provoling heated attacks from all quarters on the regulatory policies of the Civil Aeronautics Board. ${ }^{3}$ Spokesmen for the air industry claim that indiscriminate granting of route certificates has resulted in undue and destructive competition; ${ }^{4}$ new concerns, seeking entrance into the industry, complain of Board exclusionary policy. Galvanized into action by $\mathrm{CAB}$ proposals calculated to capture large volumes of rail revenue, the railroads demand an end to all government aid to the airlines; ${ }^{5}$ combine with other surface carriers to attack the Board policy which bars them from control of air carriers; ${ }^{\circ}$ and even go so far as to propose the abolition of the CAB. ${ }^{\text {T }}$

1. The aggregate net operating loss of the airline industry for the first six months of 1947 is placed at 17.4 million dollars as compared with a total deficit for the calendar year 1946 of 5.8 million dollars. H. R. ReP. No. 1612, 80th Cong., 2d Sess. 7 (1948).

2. E.g., Congressional Aviation Policy Board (Brewster Committee; national defense and air power; Report: SEN. REP. No. 949, S0th Cong., 2d Sess. (1948)) ; President's Air Policy Commission (Finletter Commission; national defense, military aviation, aircraft manufacturing, civil air transport; report: Survival m The AIR AGE (1948)) ; Committee on Post Office and Civil Service (Rees Committee), authorized by H. Res. No. 176, 80th Cong., 1st Sess. (1947) (air mail carriage, payments and subsidies). See also Aitchison, After the War Is Over-Transportation Problems, 11 I.C.C. Pract. J. 743 (1944).

3. - Hereinafter referred to as the CAB or the Board.

4. Executives of the major airlines vehemently contend that the $C A B$ has favored a policy of "competition for competition's sake" and has indulged in the practice of "cutting down" the larger airlines. 47 Avtation Ween No. 13, p. 28 (Sept. 29, 1947). The $\mathrm{CAB}$ is frequently accused of having embarked on a program of making big lines out of small lines and of granting route extensions that result in parallel service, both of which lead to "competition." Smith, C. R, Air Transportation, Its Stalus, Trend and Prospect, 14 J. Ann L. 150 (1947) (Chairman of the Board, American Airlines and President of American Overseas Airlines).

5. Government assistance takes the form of airmail payments in excess of the value of the services rendered by the airlines; the erection and maintenance of the navigational and safety aids comprising the "airways"; and the provision of airport facilities at fees lower than the cost of the service. Total public aid to domestic carriers through 1946 is estimated at $\$ 207,268,113$. H. R. Rep. No. 1612, 80th Cong., 2d Sess. 14 (1948). See p. 1082 infro.

6. See p. 1065 infra.

7. This pressure of the railroads is perhaps the main reason for the current studies of the House Committee on Interstate and Foreign Commerce, lnown as the "National Transportation Inquiry". Authority to investigate was granted in H. Res. No. 318, 79th Cong., 1st Sess. (1945), and continued in H. Res. No. 153, 80th Cong., 1st Sess. (1947). The modes of transportation presently regulated by the ICC favor a single agency to control all transportation; the airlines wish to preserve their separate agency, the CAB. In the event that all transport regulations were to be centered in the ICC, the motor and water carriers request that the commission be reorganized. The railroads alone insist that the present organization of the ICC be retained, and, further, that all the means of transport within the area be integrated. Users of transportation are about split on the matter of "integration": $49 \%$ not in favor; $51 \%$ favorably disposed but with the important qualifieation that a monopoly should not result. House Sub-Commiltec Report on National Trans- 
Confronted with these partisan attacks as well as with the task of conditioning and directing the future growth of a dynamic industry, ${ }^{8}$ the Board, forced to defend its position, has sought to explain away the present unhappy state of the industry ${ }^{9}$ as a period of temporary losses incurred through large preparatory expenditures aimed at increasing future cargo and passenger revenues. ${ }^{10}$ However, in simultaneously ordering investigations into possibly

portation Inquiry, 14 I.C.C. PRACT. J. 296 (1947). For a note of opposition, see WIprUd, Justice IN Transportation 140 et seq. (1945). See Cunningham, The Transportation Problem, 25 HARv. Bus. REv. 58 (1946) (suggesting aviation is out of infancy and should not be singled out for special promotional treatment); Brownell, The Air Coordinating Committee, 14 J. AIR L. 405, 410 et seq. (1947) (discussing possible departmental reorganizations, such as, Dep't of Air, Dep't of Civil Aviation, Dep't of Transportation or a Dep't of National Defense). The suggestion has been advanced that "competitive forces ... be permitted to determine the proper territorial and functional sphere for each mode of transportation, on condition that provision be made to assure the continued existence of each although perhaps in a seriously modified form." This would be in the nature of a compromise between an administrative agency basing rates on costs and permitting competition only on a service level; and the coordination of all transport which presents the powerful carriers with a chance to dominate. Schrag, Competing Modes of Transportation and the I. C. C., 94 U. of PA. L. REv. 378, 399 (1946).

8. Air transportation today is in the same relative state of development as the railroads were 100 years ago. The $\mathrm{CAB}$ was established as the regulatory agency only 12 years after the first regularly scheduled flight, whereas the ICC was made an effective supervisory body in 1920 by the National Transportation Act, approximately 90 years after the birth of the railroads.

Comparative statistics highlight the rapid growth of air transport. Typical are the figures of revenue passenger miles reported by the sixteen certificated domestic airlines:

$$
\begin{aligned}
& 1935 \text { (fiscal year) 221,915,595 } \\
& 1946 \text { (fiscal year) 4,526,391,220 } \\
& 1947 \text { (Jan. through Sept.) 4,580,508,000 }
\end{aligned}
$$

C.A.B. ANN. REp. 47 (1941) ; ibid. 38 (1946) ; C.C.A. Jour. 140 (Dec. 15, 1947).

See generally Barnes, The Economic Role of Air Transportation, 11 LAw \& CoNTEMr. Proв. 431, 443 (1946). See also Burden, Postwar Status of the Aircraft Indiustry, 23 HARv. Bus. Rev. 211 (1945) (postwar growth and effect on employment) ; I.C.C. BuREAU of Transport Economics and Statistics, Some Aspects of Post War Air and Surface Transportation (1945) (analysis of growth prospects); Wright, Aviation's Place In Civilizatron 22 (1945) (United States employment forecast for aviation and related industries 8 to 12 years after the end of the war- $-610,000$ ). Industry executives forecast a thirty-fold growth within twenty years of the war's end. This would entail the carriage of $80 \%$ of all pullman fares, $40 \%$ of rail express, $33 \%$ of rail coach traffic, $80 \%$ of the parcel post shipments, $20 \%$ of the rail "less than carload" freight, and $5 \%$ of the motor bus traffic. Patterson, Some Views on Post-War Aviation (1944) (President of United Air Lines).

9. National Airlines, Inc., Mail Rates, 7 C.A.B. 387, 405 (1946). See SuRvival IN the AIr Age 99 (1948) (Report of the President's Air Policy Commission which list some causes of the difficulties); hereinafter referred to as the REPORT. All the various forms of transportation currently are exhibiting signs of weakness. La Roe, $A$ Weak Transportation System, 14 I.C.C. Pracr. J. 327 (1947).

10. In the period July 1, 1945 to July 1, 1947, the 16 certificated domestic airlines spent $\$ 235,000,000$ for capital assets (largely planes), which sum is more than eight times the total investment of the airlines in property and equipment at the outset of 1945. 47 AviATION WEEK No. 18, p. 51 (Nov. 3, 1947). In addition to the vast expenses incurred in 
uneconomic route characteristics, ${ }^{11}$ the $C A B$ has suggested that it is less than certain of its announced position. Current dislocation may not be transitory; inquiry may reveal fundamental wealnesses incorporated into the air transportation system by past regulatory policy.

\section{Regulatory Contror}

Passed to salvage an industry that was described as in a state of "chaos," 12 the Civil Aeronautics Act of $1938,{ }^{13}$ setting up the Civil Aeronautics Authority, the forerunner of the $C A B,{ }^{14}$ was the first comprehensive legislation in the field of air transportation. ${ }^{15}$ Under the CAA air safety was regulated on

procuring capital assets, the airlines must expend sums training personnel for expanded air operations.

11. Investigation of Chicago and Southern Air Lines, Inc, C.A.B. Doc. 2\&62, Order E-401 (March 24, 1947) (mimeo) ; Investigation of Northeast Airlines, Inc, C.A.B. Doc. 2853, Order E-375 (March 18, 1947) (mimeo); Investigation of Western Air Iines, Inc, C.A.B. Doc. 2911, Order E-485 (April 29, 1947) (mimeo) ; Investigation of Colonial Airlines, Inc., C.A.B. Doc. 2852, Order E-373 (MIarch 18, 1947) (mimeo); Investigation of Pennsylvania-Central Airlines Corp., C.A.B. Doc 2883, Order E-437 (April 7, 1947) (mimeo). These inquiries are conducted under authority of CAA $\$ \$ 205(3), 407(a)$, 415,1002 (b). Board Member Lee dissented in some of the cases, stating that such investigations should not be authorized without the consent of the airline involved.

Simultaneously an inquiry was ordered into the operations of All-American Aviation under the authority of $\$ 401$ (h) with a view to the possible modification, suspension, or revocation of the certificate. This was deemed necessary since All-American had lost \$119,877 in 1946 despite an increase in its mail rate on Sept. 1, 1946, from 49.76 cents per airplane mile to 57.91 cents. Investigation of All-American Aviation, Inc, C.A.B. Doc 2918, Order E-494 (May 2, 1947) (mimeo).

12. C.A.A. ANN. REP. 1 (1939); see p. 1059 infra.

13. 52 StaT. 977 (1938), 49 U.S.C. $\$ \$ 401-682$ (1940) (hereinafter referred to as the Act or the CAA). See Rhyse, CIVI Aeronautics ACT, Annotated (1939).

14. The functions of the Civil Aeronautics Authority were consolidated with the functions of the Air Safety Board, and the merged body was redesignated the Civil Aeronautics Board and transferred to the Department of Commerce for "houseliecping" purposes. Reorg. Plan IV (1940), 54 Star. 1235 (1940).

15. In general, air mail had been the main concern of previous legislation, although in 1934 restrictions were placed on interlocking control, mergers, and certain other phases of corporate life. See 43 STAT. 805 (1925), 39 U.S.C. $\$ 461$ et seq. (1940) (Air Xrail Act of 1925) ; 44 STAT. 568 (1926), 49 U.S.C. $\$ 171$ et seq. (1940) (Air Commerce Act of 1926); 45 Stat. 594 (1928); 46 Stat. 259 (1930) (McNary-Watres Act); 48 Stat. 933 (1934), 39 U.S.C. $\$ 461$ et seq. (1940) (Air Mail Act of 1934). In connection with these enactments and the history of commercial aviation, consult Ruysre, op. cit. supra note 13; Frederick, Conmiercial Am Transportation (1947); Pugfer, Am Tramsromatro:i (1941) ; Spencer, ATr Matr Pavarent aNd the Governarewt (1941). Fredizicin, sispro, and PUFFer, supra, treat many phases of the air transport problem. Alost articles on commercial aviation devote at least a few pages to a treatment of the general history. See eg., Hamstra, Two Decades-Federal Acro-Regulation in Perspective, $12 \mathrm{~J}$. Am I. 105 (1941) ; Ballard, Federal Regulationt of Aviation, $60 \mathrm{HARV}$. L. REv. 1235 (1947) ; 1 AmePORTS 42 (1947) ; David, Federal Regulatiost of Airplane Comsnon Carricrs, $6 \mathrm{~J}$. Lnsid \& Pus. UtIL. Econ. 359 (1930). Roberts, Outlook for Post-War Aviation Law, 33 Geo. L. J. 452 (1945).

Before the CAA of 1938, aviation's activities were handled by many separate depart- 
the widest possible scale; ${ }^{16}$ and economic control ${ }^{17}$ was imposed upon all airlines engaged as common carriers in non-intrastate transport of mail, or of persons and property. ${ }^{18}$ In light of current constitutional interpretation of national power in the commerce field, ${ }^{19}$ the statutory limitation of $\mathrm{CAB}$ authority to interstate air commerce has lost much of its significance and today it is within the power of the Board to develop a nationally integrated airline system. ${ }^{20}$

Drawing on experience gained from other legislation regulating private

ments: Post Office Dep't (mail contracts); Interstate Commerce Commission (rates); Department of Commerce (airways and safety regulation); Department of Agriculture (weather reports); the Departments of State, War, Navy and the Treasury were involved in varying degrees. Altschul, Economic Regulation of Air Transport, 12 J. AIR L. 163 (1941).

For a comprehensive picture of the vast number of agencies and departments which even today are connected with aviation issues, consult Brownell, sippra note 7, table at 407 (1947).

16. The CAB possesses power to regulate safety of flight in "air commerce." 52 STAT. 1007 (1938), 49 U.S.C. §551(a) (1940), CAA \$601(a) (1938). "Air commerce" is a comprehensive classification embracing "interstate, overseas, or foreign air commercc or the transportation of mail by aircraft or any operation or navigation of aircraft within the limits of any civil airway or any operation or navigation of aircraft which directly affects, or which may endanger safety in, interstate, overseas, or foreign air commerce." 52 StAT. 977 (1938), 49 U.S.C. $\$ 401(3)(1940)$, CAA §1(3) (1938). The safety provisions of the Act are further amplified by the Civil Air Regulations issued by the CAB. 52 STAT. 1007-12 (1938), 49 U.S.C. $\$ \$ 51-60$ (1940), CAA $\$ \$ 601-10$ (1938); 14 CODE FED. ReGs. (Cum. Supp. 1943) \& .01 et seq.

17. 52 SтAт. 987 (1938), 49 U.S.C. $\S \$ 481-95$ (1940), CAA $\S \S 401-16$ (1938).

18. Economic regulation, as compared with the supervision of safety, is limited in scope due to a narrow definition given to "air transportation." 52 STAT. 987 (1938), 49 U.S.C. $\$ 481$ (a) (1940), CAA § 401 (a) (1938); 52 STAT. 977 (1938), 49 U.S.C. $\$ 401$ (10) (1940), CAA § 1(10) (1938); see note 15 supra. See also Rhyne, Fedcral, State and Local Jurisdiction Over Civil Aviation, 11 LAw \& ContenIP. Pros. 459, 465 (1946); Current Status of Aviation Law-American Bar Association Commerce Report, 14 J. Alr L. 217, 220 (1947).

19. North American Co. v. S.E.C., 327 U.S. 686 (1946) ; United States v. Darby, 312 U.S. 100, 118 et seq. (1941) and cases cited, reversing 32 F. Supp. 734 (S.D. Ga. 1940); U.S. v. Wrightwood Dairy Co., 315 U.S. 110 (1942), reversing 123 F.2d 100 (C.C.A. 7th 1941); Houston, East and West Texas Ry. Company v. United States, 234 U.S. 342 (1914).

20. For an example illustrating the Board's broad power over the intrastate phase of an interstate trip, see CAB v. Canadian Colonial Airways, 41 F. Supp. 1006 (S.D.N.Y. 1940) (carrier operating between New York City and Niagara Falls, New York); C.A.B. ANN. REP. 36 (1941). The argument of state versus federal jurisdiction still rages. Sec Hamley, Appropriate Areas of State Economic Regulation, 11 LaW \& ConTEMr. Rrov. 488 (1946) ; Rhyne, supra note 18, at 466 et seq.; Ryan, Economic Regulation of Air Commerce by States, 31 VA. L. Rev. 479 (1945) (member of the CAB advising that all control be centered in the Board) ; Binzer, Civil Aviution-The Relative Scope of Jurisdiction of the State and Federal Government, 33 Kx. L. R. 276 (1945); Ryan, Fedcral and State Jurisdiction Over Civil Aviation, 12 J. A.R L. 25 (1941); Willebrandt, Fedcral Control of Air Commerce, 11 J. AIR L. 204 (1940) (federal government has so thoroughly regulated that only role left to the states is to assist where possible). 
enterprise, ${ }^{21}$ Congress provided that no air carrier coming within the purviev of the statute was to operate without a certificate of public convenience and necessity ${ }^{22}$ issued by the CAB to a carrier "fit, willing, and able" to effectuate a proposed operation in the "public interest." 23 In a departure from legislative custom, Congress commanded the CAB to point toward certain specific goals in effectuating the "public interest": ${ }^{24}$ the encouragement and development of an air transportation system properly adapted to the present and future needs of foreign and domestic commerce, the Postal Service, and national defense; the regulation and coordination of such a system to assure adequate and economical service; and the utilization of competition "to the extent necessary" to attain these objectives. Pursuant to the "grandfather clause," established carriers were to be granted the necessary certificates upon a mere showing of continuous and satisfactory service. ${ }^{25}$

21. See James, Air Carrier Regulation, 34 Ils. B. J. 193 (1946); Stough, Organization and Procedures of the Cizil Acronastics Board, 11 I.C.C. PrAct. J. 372 (1944).

22. Some elements in Congress desired unlimited competition but the Post Office Department, opposed to such a stand, eventually was successful. Goopssn, Gorernassers Policy Toward Comsiercial Aviation 1 (1944). The "certificate of public convenience and necessity" has been described unfavorably as a "legal device to keep air transportation from developing more rapidly than is convenient for vested interests." WIrnud, op. cit. supra note 7, at $\mathrm{X}$.

23. "The Board shall issue a certificate . . . if it finds that the applicant is fit, zilling, and able to perform such transportation ... and that such transportation is required by the public convenience and necessity. ..." 52 Stat. 987, 49 U.S.C. $\$ 481$ (d) (1) (1940), CAA $\S 401$ (d) (1) (1938) (emphasis added).

24. "National interest in the narrowly commercial aspects of aviation is overshadowed by the importance of air transport as an instrument of national policy-economic, diplomatic, and military." Lissitzyn, International AIR Transport 94 (1945).

The Act's provision reads that, "In the exercise and performance of its powers and duties under this chapter, the Board shall consider the following, among other things, as being in the public interest ...

(a) The encouragement and development of an air-transportation system properly adapted to the present and future needs of the foreign and domestic commerce of the United States, of the Postal Service, and of the national defense;

(b) The regulation of air transportation in such manner as to recognize and preserve the inherent advantages of, assure the highest degree of safety in, and foster sound economic conditions in, such transportation, and to improve the relations between, and coordinate transportation by, air carriers;

(c) The promotion of adequate, economical, and efficient service by air carriers at reasonable charges, without unjust discriminations, undue preferences or advantages, or unfair or destructive competitive practices;

(d) Competition to the extent necessary to assure the sound development of an airtransportation system properly adapted to the needs of the foreign and domestic commerce of the United States, of the Postal Service, and of the national defense;

(e) The regulation of air commerce in such a manner as to best promote its development and safety; and

(f) The encouragement and development of civil aeronautics."

52 StAT. 980 (1938), 49 U.S.C. $\$ 402$ (1940), CAA $\$ 2$ (1938).

25. Those airlines in operation during the period Mfay 14, 1938, to August 22, 1938, 
To implement the affirmative promotional duty in addition to the regulatory function, Congress authorized the Board to provide financial assistance in the form of air mail payments to any certificated carrier which, under honest, efficient, and economical management was contributing to the advancement of the industry. This aid was to take the form of airmail payments bearing no relation to the value of the services rendered by the air carrier but designed to underwrite any operating deficit with the "efficient" carrier receiving an additional amount calculated to guarantee a return on investment and to spur incentive. ${ }^{26}$

Completing the supervisory pattern, Congress granted the $\mathrm{CAB}$ extensive authority to regulate the economic structure and operation of the industry. ${ }^{27}$ And most important, Congress provided that Board sanction of the acts of an air carrier should cloak the participant with immunity from the operation of the antitrust laws and the scrutiny of the Department of Justice. ${ }^{28}$

\section{ECONOMIC CHARACTERISTICS OF THE INDUSTRY}

Provided with regulatory machinery by the Civil Aeronautics Act, the Board was confronted with the problem of operating it in the context of the inherent economic characteristics of the air transport industry. The $\mathrm{CAB}$ could make little use of analogy to other fields of public utility regulation, for the airline industry, when unregulated, possesses few characteristics of a natural monopoly.

Absent regulation, ease of entry into air transportation is a prime factor conducing toward free competition within the industry. By the standards of large scale transportation, relatively little capital is required of the commercial airline since the federal government erects and maintains the exten-

were eligible for such certificates. 52 STAT. 987 (1938), 49 U.S.C. $\$ 481$ (e)(1) (1940), CAA $\$ 401(\mathrm{e})(1)$ (1938). Many Board members have stated that these "grandfather" routes constituted an ill-advised air pattern which has constantly plagued the CAB in its administrative action. See former Chairman Landis' dissent at p. 40 in Western-United Acquisition of Denver-Los Angeles Route, C.A.B. Doc. No. 2839, Order E-772 (Aug. 25, 1947) (mimeo).

26. "In determining the rate [for the carringe of air mail] in each case the Board shall take into consideration ... the need of each such carrier for compensation for the transportation of mail sufficient to insure the performance of such service, and, together with all other revenues of the air carrier, to enable such air carrier under honest, economical, and efficient management, to maintain and continue the development of air transportation. . .." 52 StaT. 998 (1938), 49 U.S.C. $\$ 486$ (b) (1940), CAA \&406(b) (1938). See p. 1083 infra.

27. The $C A B$ is given sweeping control over: accounting practices and reports; approval or disapproval of mergers, consolidations, sales, interlocking directorships, and loans by government agencies to the airlines; and methods of competition. Perhaps one of the most important powers is the right of the Board to establish appropriate classifications of air carriers for regulatory treatment. 52 STAT. 1000 et seq. (1938), 49 U.S.C. $\$ 487$ et scq. (1940), CAA § 407 et seq. (1938).

28. 52 Stat. 1004 (1938), 49 U.S.C. $\$ 494$ (1940), CAA $\S 414$ (1938). This has been a point of much contention. For an advocate of free competition with the Department 
sive "airways," the highways of the air; " federal and local funds provide the airports whose capacity is perhaps the most important physical limitation on the scope of air operations. This freedom from a large fixed investment assures low fixed charges and relates success more to efficient managerial control of high variable expenses than to possession of great resources. In addition, less capital is required since the great speed and flexibility of aircraft renders each unit of capital highly productive. $\$$ And considering ventures of approximately equal risk, it is relatively less difficult to obtain funds for investment in air transportation because of the great public interest in its prospective development. ${ }^{31}$ Finally, technological progress plays a more important role in air transportation than in any other transport medium, exercising a profound effect on the basic determinants of air traffic and providing an atmosphere wherein competitive forces may operate in the exploitation of new techniques and equipment.

A finite air traffic potential, and the very facility with which new concerns could enter the industry served to produce the relentless competition and "chaos" that characterized the industry before the CAB. This economic instability among smaller firms and the serious repercussion of cutthroat competition upon the safety factor in public air transportation urgently demanded attention. At the other pole, technological change, the operational advantages of large aircraft, and the importance of a high utilization of available plane space were operating to mould an ever tightening core of oligopoly, ${ }^{32}$ advocated by the major lines as the panacea for the ills of destructive rivalry. The "cure" developing was but another illness, for in it lay the germs of monopolistic inefficiency, reduced emphasis on technology and cost, and inflexible rate schedules. To cope with this anomalous coexistence of cut-

of Justice as the guardian against monopoly, see WIPEUD, op. cit supra note 7 (foreword by Thurman Arnold). The defense of the regulatory agencies, the ICC and CAB, is presented in Drayton, Transportation Under Two Mlasters (1945) (foreword by Bernard Baruch); Smith, Application of Anti-Trust Law's to Regulated Industrics, 14 I.C.C. PRACT. J. 181 (1947).

29. 52 StAT. 985 (1938), 49 U.S.C. $\$ 452$ (1940), CAA $\$ 302$ (1938). See note 5 supra.

30. In 1941, the amount of capital investment required to produce $\$ 1$ of operating revenues was: airlines, $\$ 1.13$; bus lines, $\$ 1.30$; Class I line-haul railroads, $\$ 4.90$. The railroad industry has a higher figure because of the sums invested in rights-of-way and terminals. See Crane, The Economics of Air Transportation, 22 Honv. Bus. REv. 495, 496 (1944). It is estimated that " 40,000 planes at 20 ton capacity could produce the same number of ton-miles in one year as the entire railroad system of the United States with its 134 millions of freight cars and some 40,000 locomotives. ..." Wulnuss, The Ournoor Fon Dodrestic AIR Transport (Planning Pamphlet No. 21 1943).

31. Probably based on an appreciation of the government's airmail "subsidy" payment policy. See p. 1083 infra.

32. The members of this oligopoly, American Airlines, United Air Lines, Transcontinental and Western Air, and Eastern Air Lines, were products of the flurry of merger, consolidations and sales that followed Charles Lindbergh's transatlantic flight. 
throat competition and oligopoly, some type of regulation was imperative ${ }^{33}$ if air transportation was to attain full stature and become an integrated element of the national transportation scheme.

\section{Civil Aeronautics Board Policy}

\section{Balanced Competition}

As the touchstone for the regulation of America's air system, the CAB has evolved a basic philosophy of "balanced competition." 34 Although subordinate phases are not clearly enunciated, the theory of "balanced competition" appears to be predicated on a stratification of the airlines into categories having common economic characteristics. ${ }^{35}$ The objective is to maintain "balanced competition", as opposed to undue rivalry, within each of these classifications, and in fact gradually to strengthen the smaller air carriers by the addition of new routes and the extension of existing service..$^{30}$ Such an affirmative policy, unique in regulated industries, would tend to place the smaller airlines on a sound basis to offer competition to the paralleling sections of the larger systems. ${ }^{37}$ And implicit in the theory of balanced

33. See Healy, Workáble Competition in Air Transportation, 35 AnEp Econ. Rev. Supp. 229 (1945).

34. This policy was first enunciated in United Air Lines Transport Corp. Acquisition of Western Air Express Corp., 1 C.A.A. 739 (1940). In this connection see generally Highsaw and Burt, Competition Under the C.A.A., 6 LA. L. REv. 148, 157 et seq. (1945); Melone, Controlled Competition: Three Years of the Civil Acronantics Act, $12 \mathrm{~J}$. AxR L. 318 (1941).

35. Crane has classified the airlines in order of decreasing size as follows:

Class I: American, United, TWA, Eastern

Class II : Northwest, Pennsylvania-Central, Braniff, Chicago and Southern

Class III : Western, Delta, Mid-Continent

Class IV : National, Continental, Inland, Northeast

Omitted : Canadian Colonial, All American Aviation, and Catalina.

This categorization is based on a mass of criteria; passenger-miles performed, seat-miles performed, revenue-miles flown, capacity ton-miles or service offered, miles of route, total assets, book value of real property and equipment, and operating expense. Crane, supra note 30, at 501 et seq. See also, Barnes, sutpra note 8, at 433. Northwest more properly should be classified as the fourth transcontinental carrier and listed in Class I, see note 37 infra.

36. E.g. Mid-Continent Air, Kansas City-New Orleans, 6 C.A.B. 253, 262 (1945) (strengthening of Midcontinent); Colonial Air, Washington-Ottawa-Montreal, 6 C.A.B. 481, 501 (1945) (strengthening of Colonial) ; Colonial Air., Atlantic Seaboard Operation, 4 C.A.B. 552, 560 (1944) (strengthening of National to compete between New York City and Miami, Florida, with Eastern Airlines).

37. In certain rare instances a smaller carrier will be tacitly reclassified on a multiple showing of efficiency and growth of region served. The most notable instance of this is Northwest Airlines which has become the fourth transcontinental carrier with routes from New York City and Washington, D. C. to Seattle, Washington, and on to Tokyo, Japan, Shanghai, China, and Manila, P. I., Northwest Airlines, Chicago-Milwaukee-New York Service, 6 C.A.B. 217 (1944) (entry into New York) ; Northwest Airlines, Pacific Case, 7 C.A.B. 209 (1946); 7 C.A.B. 599 (1946) (supplemental) (entry into Alaska, Japan, China, and the Philippines); Northwest Airlines, Detroit-Washington Service, C.A.B. Doc. No. 679, Order E-861 (Sept. 30, 1947) (mimeo) (entry into Washington, D. C.) 
competition is a rejection of the concept of a "super-carrier" or "chosen instrument" to exploit a specific market. ${ }^{39}$

While this theory seems generally desirable as an approach to the regulation of the airlines, ${ }^{39}$ the effectiveness with which the CAB has applied it is open to serious question.

\section{Entry into the Industry}

Ease of entry into air transportation provided the $\mathrm{CAB}$ with $a$ fertile source of competitive stimulus which might have been controlled in the public interest. Great numbers of applicants, attracted by the apparently limitless prospects for air commerce, filed for certificates both to serve new territories and to compete with existing airlines between cities already certificated.

Thus the Board early was called upon to formulate its policy on new entrants. Initial encouraging indications that new firms would be welcomed proved shortlived; ${ }^{40}$ for in the leading case of Delta, Birmingham-Pittsburgh, ${ }^{42}$

38. "The question whether as a matter of policy United States international Air transportation shail be rendered by a single company or by a 'chosen instrument' . . was settled by Congress in the Civil Aeronautics Act of 1938 when . . . Congress provided that this Board in its decisions in new route cases, both domestic and international, should consider as being in the public interest... "competition to the extent necessary. . . ." Northeast Air., North Atlantic Routes, 6 C.A.B. 319, 323 (1945). Pan American's claim to "chosen instrument" status is opposed by all domestic air carriers exeept United Air Lines which bases its position on the alleged insufficiency of transocean traffic to varrant competition.

39. It is the Board's position that "[r]eference to both the legislative history and to the text of the Act demonstrates the Congressional intent to safeguard an industry of vital importance to the commercial and defense interests of the nation against the evils of unrestrained competition on one hand, and the consequences of monopolistic control on the other." Acquisition of Western by United Air Lines, 1 C.A.A. 739, 749 (1940). See also Healy, supra note 33, at 229.

40. In the American Export case, 2 C.A.B. 16 (1940), a certificate was granted to an aggressive new firm to operate transatlantic service in competition with the "benevolent" monopoly of Pan American Airways. And the principle seemed to have been settled that established air carriers were to be given no precedence in the development of new services when the Board in the All-American case, 2 C.A.B. 133 (1940), approved the issue of a certificate to a newly organized company to operate a novel pick-up device for airmail carriage eliminating the necessity of a landing. In the latter decision, the $C A B$ was unequivocal in its statement that: "Any such theory as advocated by the interveners [TWA and Eastern Air Lines, existing carriers], which would result in reserving solely for existing air-lines the privilege of providing all additions to the present air-transportation system of the United States, is untenable. Our adoption of such a policy would certainly not be consistent with a sound development of air transportation, and would not be conducive to the best interests of the foreign and domestic commerce of the United States, the Postal Service, and the national defense" Id. at 146. See Hamstra, Watson, and Barber, Monopoly Versus Competition in Air Routes under the C.A.A., 12 J. Ars L. 280 (1941).

For an account of the severe competition that American Export Airlines cncountered from Pan American Airways, consult Josephison, JuAN TrIppe AND tHe Struggle fos WORLD AIRWAYs 139 et seq. (1943). Interesting light is cast both on the magnitude of Pan American's lobbying and incidental expenditures, $i d$. at 140 , and on the characterization of the globe straddling airline by one of its own directors as a "benevolent, democratic monopoly." Id. at 202.

41. 2 C.A.B. 447 (1941). This decision came but six months after the result in the All-American case. 
the Board laid down a canon of exclusion. Four applicants, two of which were operating air carriers, were competing for various routes in the southern states. The application of one of the new firms was denied on the ground that the concern while "willing", lacked adequate finances and was not "fit" and "able" to provide the desired transportation. But in the disposition of the other new concern, an organization with sufficient funds that could not be dismissed under the "fit, willing, and able" formula," 42 the Board first enunciated what was to be its philosophy on new entrants: the present number of carriers in air transportation was deemed sufficient to protect against monopoly, and any future expansion of air transportation would best be accomplished by the certification of presently operating air carriers. ${ }^{43}$

This startling rule banning new concerns from air transportation has since dominated Board policy with but one fleeting exception. Board investigation ${ }^{44}$ had revealed a limited market potential immediately available in local service or "feeder" operations, 45 and the CAB determined to treat this new problem as an "unusual circumstance." Accordingly, newly entering concerns, native to the area to be served, were certificated; and the applications of the established airlines were dismissed. ${ }^{46}$

Unrestricted entry even in this field proved transitory, however. When local airlines reported sharply rising operating costs in excess of estimates,

42. No attempt was made to dispose of this applicant on the grounds of insufficient funds; the $\mathrm{CAB}$ unequivocally stated: "The record indicates that this company will be adequately financed." Delta, Birmingham-Pittsburgh, 2 C.A.B. 447, 479 (1941).

43. Id. at 480. In view of this later case, the American Export and All-American decisions, note 40 supra, must be relegated to the easily distinguishable category of "unusual circumstances." Viable new concerns had to be certificated in these instances since existing airlines had exhibited great reluctance either to oppose Pan American Airways in the one instance or to develop new devices and techniques similar to the pick-up mechanism in the other case.

44. Investigation of Local, Feeder, and Pickup Air Service, 6 C.A.B. 1 (1944).

45. The examiner's exhaustive analysis of local traffic possibilities stressed the importance of operating economies if successful operations were to be achieved. Smaller aircraft, single pilot operation, elimination of luxury services, and reduction of intermediate station personnel were among the suggestions which eventually caused the Board to consider this service as differing from that presently performed by the certificated airlines. $I d$. at 4. Many operating plans for the prospective new carriers were reviewed and evaluated. Some were based on the trading area while others concentrated on serving a specific city, fanning out in spokelike fashion. Id. at 30 et seq. See also in this connection, FreDERICK, op. cit. supra note 15, at 203 et seq. Attention was called to the fact that the airplane is essentially an instrument of long distance transport. Statistics showed that the average passenger journey was 450 miles and the most common trip was 250 miles. Airlines endeavoring to operate over shorter distances would be in sharper competition with the highly developed surface transportation system. Investigation of Local, Feeder, and Piclup Service, 6 C.A.B. 1, 2, 47 (1944); Nicholson, Possibilities for Lower Airline Costs, 11 Law \& Contensp. Prob. 452, 454 et seq. (1946). For an analysis of the prospective market for feeders, see Frederick and Hudson, Sources of Feeder Line Business, 13 J. AIr L. 99115, 212-27, 302-20 (1942) ; FREDERICK, op. cit. sitpra note 15 at 212 et seq.

46. Typical of the comprehensive plans for expansion of the major airlines into local or "feeder" service was the costly analysis made by Transcontinental and Western. TWA 
the $C A B$, ignoring the fact that a similar trend existed concurrently among the older airlines, altered its policy and in subsequent route proceedings assigned the new cities and towns to the routes of established airlines as intermediate stops. ${ }^{47}$

The $\mathrm{CAB}$ has experienced no difficulty in effectuating its exclusionary philosophy. The "fit, willing, and able" formula has become the usual Board device for denying a certificate to a new applicant, and while it is true that attention must be paid to this standard in the interests of air safety, the criterion serves only to preserve the status quo when regarded by the $C A B$ as a blind requirement of possession of adequate finances, experienced aviation personnel, and detailed plans for subsequent operation in the event of certification. ${ }^{43}$ Quite often ample financing is available but contingent on the award of a certificate which in turn is conditioned on the possession of the factors themselves. 49 The result is that the arbitrary use of the "fit" and "able" tag can lead to dismissal of an application where no actual insufficiency of funds will exist. ${ }^{\text {so }}$

desired "to concentrate on development of its present territory and to render intermediate cities on or adjacent to its present routes the highest possible service" A state by state exposition of its proposal was presented with extreme emphasis on service to cren the smallest hamiet by "multi-engine, luxury airliners." The Aurunse as:d Youn Cosnsumint: 2,6 (1943). The cities involved were tacitly invited to intervene in the route proceeding. Id. at 64 et seq. Compare this offer of "multi-engine, luxury airliners" with Investigation of Local, Feeder, and Pickup, 6 C.A.B. 1, 9 et seq. (1944) (examiners report). See note 45 supra.

47. Great Lakes Area Case, C.A.B. Doc. No. 535, Order E-783 (Sept. 3, 1947) (mimeo). In the next regional case, the $\mathrm{CAB}$ altered its policy once again and placed the new cities on the routes of previously certificated "feeders", thereby creating a "superfeeder" with access to greater population pools over which to apportion fixed changes. Mississippi Valley Case, C.A.B. Doc. No. 548, Order E-1060 (Dec. 18, 1947) (mimeo). In any event, the major airlines consider the creation of feeder airlines to be dangerous precedent since they fear that the local air carriers may eventually become the cores of larger systems.

48. "The Act does not define 'fit, willing, and able' but the Board has established these tests: (1) a proper organizational basis for the conduct of air transportation; (2) a plan for the conduct of the service made by competent personnel; (3) adequate financial resources." Braniff Airways v. CAB, 147 F.2d 152, 153 (App. D.C. 1945).

Further intensifying the burden of complying with the "fit" formula, Board decisions are often long delayed, generally seventeen months after the filing of an application in the average case, and in the eleven most important route cases in 1946 and early 1947 the delay between the filing of the application and the handing down of the decision averaged 1004 days. Westwood, Procedure in New Route Cases before the Civil Aeronantics Boord, $14 \mathrm{~J}$. AIR L. 267, 271 (1947).

Sluggish as $\mathrm{CAB}$ action seems to be, it compares favorably with the achievements of the I.C.C. in view of the comparative complexity of the proceedings. Id. at $272 \mathrm{n} .4$.

49. Thus, new concerns may be put to the double strain of maintaining sufficient funds for an extended period, and of retaining an experienced staff of aviation personnel who must be hired away from existing air carriers generally at increased salaries in view of the uncertain tenure. Actual cost to applicant of obtaining a certificate varies videly depending on the amount of professional assistance: an absolute minimum is considered to be $\$ 5000$, and costs may range as high as $\$ 50,000$. 1 AEREFORTS 42,52 (1947).

50. The Board has recognized "that the question of financing is inestricably bound up 
Restraint of entry in the air industry must be approached with caution, for some of the very factors that encourage new concerns to enter, also tend, if new entrants are denied, to inhibit effective exploitation of the existing market potential by airlines already in operation. Up to the present, air operations have served a "luxury" market, but future efforts to expand domestic traffic must be directed at a reduction of the rate differential between air and surface carriage. ${ }^{51}$ The availability of new frontiers, "luxury" markets in other geographical areas, and the absence of competitive compulsion have conspired to prevent exhaustive development of the traffic potential in areas presently served.

Without the competitive force provided by new entrants, the lack of a large fixed investment further reduces the compulsion to exploit existing routes. ${ }^{52}$ The railroads, with huge amounts invested in rights-of-way and terminals, are under a constant pressure to increase traffic, and thereby reduce fixed cost per unit of service; this pressure leads toward rate cutting as a technique for increasing traffic. Conversely, the small fixed investment which characterizes the air industry results in low fixed costs, and high variable expenses increase almost proportionately with expansion in operation. ${ }^{t 3}$ Reduction of air rates yields little material improvement in profit position and the existing airlines are content to forego real exploitation of the market so long as they are protected from intense competition.

Most cost factors, such as labor, equipment, and airports are offered to all lines on essentially the same terms. ${ }^{54}$ Unions have standardized rates of pay, except where regional differences are important. ${ }^{56}$ Modern airplanes, necessary to excellent service, are available to all airlines; ${ }^{b 6}$ airports which

with the major question of whether the certificate sought . . . is to be granted" but has been reluctant to relax its firm stand on the requirement save in most unusual circumstances. American Export Airlines Trans-Atlantic Service, 2 C.A.B. 16, 42 (1940). Finding a competitor for Pan American in trans-Atlantic operations was such an "unusual circumstance." Ibid.

51. See Nicholson, supra note 45.

52. See Edwards, Competitive Problems Arising from the Existence of Fixcd Costs in the Transport Industry, 12 I.C.C. PRACT. J. 1012 (1945).

53. Approximately $50 \%$ of airline costs are direct flying costs varying with the number of miles flown and a substantial part of the remainder are in proportion to service rendered. See Healy, supra note 33, at 241 . In addition, airlines have experienced a "rise in ground and indirect expenses almost as fast as tonnage volume." Nicholson, supra noto 45, at 453. In addition, as schedule frequency increased, unit costs declined only until the point of 7.8 round trips daily (with DC-3 type aircraft) and then they started to increase. Crane, supra note 30 , at 506 .

54. See Healy, supra note 33, at 229.

55. Id. at 229 n.1. Pilots' in 15 of the 16 doméstic airlines are members of the Airline Pilots Ass'n of America; mechanics of 12 of the 16 airlines are represented by Airline Mechanics Ass'n International. With respect to regional rate differentials, see Cranc, supra note 30 , at 505 .

56. One of the concrete achievements of the Air Mail Act of 1934, 48 STAT. 933 (1934), was the separation of air transport and aircraft manufacturing. However, Healy calls attention to a recent practice of informal agreements among a number of airlines to allocate 
might have charged all the traffic would bear and thereby provoked retaliatory airline combinations, have been made freely accessible at fees below cost in order to attract air transport and stimulate business. ${ }^{5 T}$ Insulated against outside stimulus, competitive forces within the industry are diverted to the level of furnishing "services".

New entrants could have supplied the competitive incentive which the Board has so eulogized. CAB policy, however, has been to restrict entry and rely on the airlines already operating to supply the necessary spur. ${ }^{\text {LS }}$ Airmail subsidies have been employed to counteract the unfavorable economic trend of the industry and the result has been a reduced emphasis on control of the sizeable variable costs, ${ }^{59}$ the most direct approach to lower rates. Thus, while publicly stating that "administrative fiat" is incapable of supplying the incentive required for the development of air transport, ${ }^{\mathrm{C}}$ the Board has been forced by its policy of restricted entry to rely on administrative techniques in an effort to achieve the goal of better service at lower rates.

\section{Entry of a Surface Carrier}

The status of the surface carrier presents a special aspect of the entry problem. Apparently inspired by a belief that growth of air transport must be at the expense of surface carriers, the Board has pursued a special policy of sharply limiting entry into the industry of surface transporters. ${ }^{01}$ To ac-

new plane types. In such a fashion a lower per unit price is obtained as tooling costs are spread over greater production, but an opportunity exists for discriminatory treatment if the $\mathrm{CAB}$ is lax in its examination of proposed agreements. See Healy, stspra note 33, at 232.

57. Ibid.

58. Criticism from diverse quarters has been heaped on the CAB. Thurman Arnold in the introduction to WIPRUD, JUSTICE IN TRANsportarios (1945) declaims: "[the] certificate of public convenience and necessity [is] a legal device to kecp air transportation from developing more rapidly than is convenient for vested interests" Id. at $x$. This volume is a plea for free, or relatively free entry. The rebuttal is containcd in DrayTON, op. cit. supra note 28 (foreword by Bernard Baruch) where the thesis is advanced that railroads and other means of transport are so carefully regulated by efficient supervisory bodies that there seems to be no justification for the Department of Justice to intervene. But cf. State of Georgia v. Pennsylvania RR, 324 U.S. 439 (1946).

59. See p. 1082 et seq. infra.

60. "Thus, economic regulation alone may not be relied on to talie the place of the stimulus which competition provides to the advancement of technique and service in air transportation. Competition invites comparisons as to equipment, costs, personnel, methods of operation, solicitation of traffic, ... all of which tend to assure the development of" the desired air system. American Export Air, Transatlantic Service, 2 C.A.B. 16, 32 (1940).

61. Many views, some of them vehement, have been advanced on this subject. See e.g. Baggett, Are Surface Carriers Grounded by Law? 31 V.. L. REv. 337 (1945); James, Control of One Form of Transportation by Anolher, 12 I.C.C. PRACr. J. 214 (1944) (surface carrier viewpoint); Tomlinson, Surface Carrier Parlicipation in Air Transportation, 34 GEo. I. J. 64 (1946); Acquisition of Conlrol of an Air Carricr By Another Common Carrier Under the Civil Acronautics Act, Note, 10 GEo. WASa. L. Rev. 719 (1942). 
complish this result, the $\mathrm{CAB}$ has utilized an extremely narrow construction of a provision in the Act which prohibits a surface carrier from "merging with or acquiring" an existing air carrier unless such surface carrier "could employ aircraft to public advantage in its operation." 62

Relying on a supposed intent of Congress to maintain independence between the various modes of transportation, ${ }^{63}$ the $C A B$ has interpreted this provision to mean that a surface carrier could only acquire an air carrier whose operations were "incidental to the surface operations" of of the surface transporter. Although the prohibition of the statute was addressed to the problem of mergers and sales, the CAB has extended this additional "incidental" criterion to restrict surface carriers seeking to enter air transportation either directly by applying for a certificate, ${ }^{65}$ or indirectly by organizing a subsidiary. ${ }^{66}$ The Board has voiced the opinion that this is a valid interpretation of legislative intent, but subsequently when actually faced with a surface carrier's application it has usually denied the application on the less vulnerable ground that some other applicant is better fitted to service the

62. 52 STAr. 1001 (1938), 49 U.S.C. $\$ 488$ (b) (1940), CAA $\S 408(b)$ (1938). The Board, itself, has characterized its interpretation as "rigid." American Export Lines, Control-American Export Airlines, 4 C.A.B. 104, 106 (1943) (supplemental).

63. This interpretation is based on a review of a series of Congressional enactments. The $C A B$ contends that as early as 1912 Congress announced a policy of independence of water carriers from railroads. Panama Canal Act, 37 STAT, 566 (1912). In 1935 there was incorporated into the Motor Carrier Act a similar restrictive provision, $\$ 213,49$ STAт. 556 (1935) which was the basis for $\S 408(\mathrm{~b})$ of the Civil Aeronautics Act. Further, Congress affirmed this policy by incorporating into the Transportation Act of 1940 the provisions of the Panama Canal Act and of $\$ 213$ of the Motor Carrier Act. 54 STAT. 909, 49 U.S.C. 5 (14-16) (1940); 54 Stat. 906, 49 U.S.C. $5(2)$ (1940). For a consideration of possible ambiguity in reenactment see American Export Lines, Control-American Export Airlines, 4 C.A.B. 104, 107 n.11 (1943) (supplemental).

64. American Export Lines, Control-American Export Airlines, 3 C.A.B. 619 (1942), 4 C.A.B. 104 (1943) ; Acquisition of TACA, S.A., by American Export Airlines, 3 C.A.B. 216 (1941) ; see note 66 , infra.

65. American Export Lines, Control-American Export Airlines, 3 C.A.B. 619, 625 (1942).

66. Ibid. The Board's original view was that the statutory prohibition was solely against acquisition of an operating airline by a surface carrier, and did nat prevent a surface carrier from organizing a subsidiary to become an air carrier. American Export Airlines, Inc,--Certificate, 2 C.A.B. 16, 46 (1940). Pan American as an intervenor, however, carried the case to the federal courts where the Circuit Court of Appeals for the Second Circuit in dictum stated that the CAB should consider the prohibition even in granting new certificates. Pan American v. Civil Aeronautics Board, 121 F.2d 810, 815 (C.C.A. 2d 1941). Thereupon, the CAB required the American Export Steamship Line to divest itself of control of the air carrier which had been granted a certificate as a subsidiary of the steamship company. American Export Airlines, 3 C.A.B. 619 (1942); 4 C.A.B. 104 (1943) (supplemental).

However, the restrictive provision does not possess a retroactive effect and any surface carrier control of an airline in effect on the date of the enactment of the Civil Aeronautics Act falls without the purview of the restrictive proviso. Railroad Control of Northeast Airlines, 4 C.A.B. 379 (1943). 
particular route, or that the particular air transportation is not warranted by the public interest. ${ }^{67}$

The basis of this specialized treatment has recently been subjected to reexamination under "unpleasant" pressure from the steamship companies. ${ }^{\circ}$ Altering its position slightly, the $\mathrm{CAB}$ conceded that Congress, while not making mandatory the application of the "incidental to surface operation" test in a situation where the surface transporter was requesting a certificate directly or indirectly, had at least enunciated the criterion as an additional guide to be considered in an evaluation of the "public interest" in the proposed operation. ${ }^{69}$ This is a distinction of dubious consequence, for it seems clear that the Board will continue to consider this "incidental" test as determinative.

The result is virtually a total ban on surface carrier entry imposed by the CAB. Legislative history does not necessarily dictate such a stand ${ }^{70}$ and it would seem to be a sounder course to disregard the superadded "incidental" test and to consider each individual application on the merits. Protection would be provided against any prospective monopoly by recourse to the "competition to the extent necessary" provision involved in a consideration of the public interest. ${ }^{71}$

However, even accepting the CAB's general thesis that applications of surface carriers must be viewed with a jaundiced eye, its application in any blanket fashion seems arbitrary. If it be argued that the $\mathrm{CAB}$ is restricting entry of surface carriers to prevent unbalancing forces within the industry, then the Board would seem justified in placing a ban on both steamship lines and railroads, since an affliation with either would tend to the creation of a "super-carrier" with access to an extensive ground organization." But if the danger assertedly to be guarded against is the entry into air transport of a surface carrier which would have little incentive to promote air expan-

67. See e.g., Braniff Airways, Kansas City-New Orleans Service, 2 C.A.B. 727 (1941); Northeast Airlines, Northatlantic Routes, 6 C.A.B. 319 (1945); Rocly Mountain Air Service, 6 C.A.B. 695 (1946); Latin American Air Service, 6 C.A.B. 657 (1946); Hawaiian Case, 7 C.A.B. 83 (1946).

68. American President Iines, Itd, 7 C.A.B. 799 (1947). Chairman Iandis in his concurring opinion comments on the extraordinary pressures brought to bear on administrative commissions and includes examples of newspaper advertising specifically directed against $\mathrm{CAB}$ policy. Id. at 818 appendix.

69. Id. at 801 et seq. The President's Air Policy Commission states that suriace carriers "should not be automatically prevented from such action (control of aircarriers) simply on the grounds that they are surface carriers-as now appears from the record to be the case." REPORT 116.

70. The legislative history is exhaustively reviewed in the concurring opinion of Chairman Iandis in American President Lines, Ltd. 7 C.A.B. 799, 814 et seq. (1947). Sce Hearings before Committee on Interstate and Foreign Commerce on Bills Relating to Overseas Air Transportation, SOth Cong., 1st Sess. (1947).

71. See note 24 supra.

72. For an example of this, see Pan American-U.S. Lines Agreement, C.AB. Doe. No. 2492, Order E-893 (Oct. 20, 1947) (mimeo) (agreement whereby a steamship operator, 
sion because of consequent harmful effects on its surface revenues, then the case of the railroad should receive more severe scrutiny than that of the steamship companies. ${ }^{73}$ Proposed expansion of air revenues is to be largely at the expense of the railroads which must protect a twenty-six billion dollar investment, ${ }^{74}$ whereas an increase in transoceanic transport would not bear too heavily on domestic steamship companies, 'since foreign shiplines carry the great bulk of the first class passenger market. ${ }^{75}$

In any event, the $\mathrm{CAB}$ by pursuing its arbitrary policy has barred a whole segment of trained capital from possible entry into air transport. ${ }^{76}$ To this extent the Board has restricted competitive forces and furthered the oligopoly existing in the industry.77

\section{Entry of Air Cargo Carriers}

In no phase of commercial aviation has the beneficial effect of competition been so vividly displayed as in the carriage of air cargo. ${ }^{78}$ This competition has not been the fruit of an affirmative program of the Board, but rather is the result of the exemption of non-scheduled operations from the requirement of a certificate of public convenience and necessity. ${ }^{79}$

Prior to the war, transportation of cargo by air was almost entirely in the hands of the air express section of the Railway Express Agency which operated under a special exemption from the certificate required of a freight for-

U.S. Lines, acted as Pan American agent in Europe and British Isles, disapproved). Pan American has engaged in similar contracts before. Pan American-Matson-Inter-Island Contract, 3 C.A.B. 540 (1942).

73. Barnes, supra note 8 , at 449.

74. Ibid. See PAtTERson, op. cit. supra note 8. In 1941, air passenger traffic was $14 \%$ of the desired $80 \%$ of the pullman market. WiLtians, op. cit. silpra note 30 , at 4 .

75. Only $15 \%$ of the United States flag steamship lines revenue in 1938 was from passenger traffic. Cunard White Star might be adversely affected by an expansion in transocean transportation by air since the major source of its 1938 revente was passenger traffic. Burden, supra note 8, at 215.

76. Needless to say, the certificated carriers agree with the CAB stand. For an independent minority view see Burgess, Transportation for America's Necds, 13 I.C.C. Prsct. J. 604 (1946).

77. One has only to recall the American Export case to appreciate the possibilitics of surface carrier participation as an instrument in combatting monopoly or oligopoly. Sce note 66 supra.

78. Air cargo is to be distinguished from air freight or express forwarding, discussed at p. 1071 infra. Concerns engaged in air cargo activity actually transport pay loads from airport to airport, whereas freight or express forwarders merely consolidate shipments and then utilize the shipping facilities offered by cargo carriers.

Excellent histories of air cargo are contained in: Frederick, American Air Cargo Development, 2 AIR AfFaIRs 79 (1947); Frederick and Lewis, History of Air Express, 12 J. AIr L. 203 (1941) ; McMillen, Air Express in the United States, 11 J. LAND AND Pub. Util. Econ. 266 (1935); 11 id. 368 (1935); 12 id. 70 (1936).

79. 14 Code Fed. REgs. $\$ 292.1$ (Cum. Supp. 1943). For an exhaustive treatment of non-scheduled carriers, consult Neal, The Status of Scheduled Operation Under the Civil Aeronautics Act of 1938, 11 Law \& Contemp. Prob. 508 (1946). See note 85 infra. 
warder. ${ }^{80}$ The ${ }^{\prime}$ Agency had separate contracts with each of the airlines whereby the cargo while aloft was the responsibility of the air carrier and the ground functions were performed by the REA. ${ }^{81}$ Disadvantages of this arrangement were long apparent to the consuming public and the certificated airlines: the promotional activities of air express were entrusted to a railway organization; the efficiencies expected of a concern which possessed a monopoly of air express did not materialize; rates were not reduced in an effort to expand the market, but rather a tendency existed to maintain the tariffs in a fixed relation to those of rail express; and by the contracts the Agency received a disproportionate share of the profits. ${ }^{82}$

A host of post-war aircraft operators utilized the exemption of nonscheduled carriers from the certificate requirement to attack this monopoly of air cargo transport. Surplus war equipment enabled these new entrepreneurs, veterans of the wartime airforces in the main, to enter into the carriage of air cargo. Competition and efficient methods of handling cargo rapidly caused a reduction in rates to a point far below those of air express ${ }^{83}$ and the speedy, reliable service become economically attractive to a constantly expanding market. ${ }^{84}$ In 1916 alone the carriage of cargo by air increased $1000 \%$.

Initially, this competition was encouraged; in exchange for a greater measure of economic control, the Board revised the exemption governing non-

80. Railway Express Agency, Grandfather Certificate, 2 C.A.B. 531, 541 (1941). The Railway Express Agency is more properly denominated a freight or express forwarder than a cargo carrier. See p. 1071 infra. However, it is necessary to consider the aetivities of the REA in an evaluation of cargo carriage for prior to Oct. 15, 1944, the Agency was the only concern that had filed schedules of rates for the transport of property by aircraft. American Airlines was the first domestic certificated air carrier to challenge this monopoly.

81. The contracts are described in detail in Railway Express Agency, Grandinther Certificate, 2 C.A.B. 531, 532 (1941). For further treatment consult Railway Express Agreements, 4 C.A.B. 157 (1943).

82. See WIPRUD, op. cit. supra note 7, at 14 et seq., 46; Frederiels and Lewis, sufro note 78, at 228 et seq.; Drew and Passen, Air Cargo: A Newo Foree in Morlecling, 14 J. AIR L. 11, 12 (1947). For a pro-REA position and a claim that the Ageney has not hampered the development of air express, see DRAYTots, op. cit. sufra note 28 , at 96 .

The Board demanded that air express rates be independent of rail express charges. Railway Express Agreements, 4 C.A.B. 157, 158 (1943). This demand, however, met with little success for even with a $25 \%$ reduction over pre-war rates the air express charges on Jan. 1, 1946 were 61 cents per ton-mile Frederich;, Ameriean Air Cargo Development, 2 AIR AfFaIRs 79, 92 (1947).

83. Today, rates for air cargo are 10 cents per ton-mile for plane lot shipments, to an average of 20-25 cents per ton-mile on smaller shipments. Air express charges are still in excess of 60 cents per ton-mile. Drew and Passen, stpra note 82, at 18. The average long-haul rail carlot rate for fruits and vegetables is approximately 1.5 cents per ton-mile. Id. at 20.

84. Newspapers, books, apparel, fabrics, flowers, etc, are among the items transported. The saving of time in cargo transport must be measured in days to appeal to the marlset; thus, short hauls are eliminated as a possible source of revenue. Id. at 14. Use of air transport has resulted in many economies: reduction of paclaging costs, inventory in- 
scheduled carriers so as to permit the larger noncertificated operators to arrange scheduled flights the better to satisfy market demand. ${ }^{85}$ Simultaneously, an inquiry was launched by the $C A B$ into all the aspects of cargo transport as a step in the formulation of the eventual economic controls to be imposed.

Abandoning individual counteraction, the certificated airlines responded to the challenge of the independents ${ }^{88}$ by establishing a joint cargo shipping organization, Air Cargo, Inc., which has been sanctioned by the CAB and thereby removed from the purview of the antitrust laws. ${ }^{87}$ Climaxing the ensuing rate war, some of the certificated lines filed schedules with the CAB quoting tariffs four percent below those of the nonscheduled operators. The $\mathrm{CAB}$ refused to suspend promulgation of these rates, ${ }^{88}$ noting that noncertificated lines recently had been given the privilege of flying scheduled operations and were, to that extent, competing on an equal basis with the certificated airlines; and that the rate war had been precipitated by the noncertificated operators who should have been cognizant of the fact that retaliatory action was possible. ${ }^{99}$ Here was an echo of free and uncontrolled competition.

Furthermore, the Board refused to entertain the claim that the certificated lines had filed rates below the cost of operation; denied that cargo deficits were being underwritten by the mail subsidies which the certificated lines alone received; and dismissed as "intended simply to confuse the issue"

vestment, warehousing and refrigeration expense; and less pilferage of and damage to the goods shipped. BUREAU of Foreign and DOMEstic CONMERCE INDUSTRY REPOIT: Domestic Transportation 7 et seq. (June 1947).

85. C.A.B. Econ. Reg. No. 389, $\$ 292.5$; see C.A.A. Jour. 61 (June 15, 1947). Exemption will continue for a limited period and will apply only to those carriers with applications for certificates pending before the Board and who were also actively engaged in cargo transport on May 5, 1947. The other phase of the new regulations for noncertificated carriers dealt with irregular carriers that may carry both passengers and property. C.A.B. Econ. Reg. No. 388, § 292.1 ; see C.A.A. Jour. 61 (June 15, 1947).

86. The only field of activity in air transport not dominated by either the certificated airlines, or by the oligopoly composed of the four largest certificated carriers is air cargo. In 1946, the nonscheduled (now uncertificated) airlines hauled the major share of freight, but only $3 \%$ of the passenger market. Freight figures showed the noncertificated airlines transporting 30 million tons to the certificated carriers' 14.83 million tons. A non-certificated carrier, Slick Airways, hauled almost as much as the combined total of the established airlines. C.A.A. Jour. 75 (July 15, 1947). It is to be expected, however, that the certificated lines, and the oligopoly, will achieve a greater share of the rapidly ex:panding market. As of March, 1947, with freight tonnage $419 \%$ over the corresponding quarter of 1946, 15 of the 16 domestic airlines were carrying freight as compared to 7 of 16 in March, 1946. C.A.A. Jour. 64 (June 15, 1947).

87. C.A.B. Order No. E-1086 (Dec. 31, 1947).

88. Air Freight Forwarder Ass'n, C.A.B. Doc. No. 3132 et al., Orders E-852 and E-853 (Oct. 2, 1947).

89. The Board dramatically characterized the position of the complaining non-certificated airlines as a "cry of 'unfairness' when the parties against whom the blow [rate cutting] has been struck retaliate in kind." Id. at 11. 
the offer of one non-certificated operator to transport the mail at his cargo rate, which was one third of the lowest mail rate paid the certificated airlines. ${ }^{30}$

This abrupt treatment of the complaints of the non-certificated carriers caused a general protest among the independent airlines over the interrelationship of mail subsidies and cargo rates. Two of the three air carriers offering to transport cargo at 14 cents a ton-mile were receiving a mail rate of 45 cents a ton-mile; one was the fortunate recipient of 60 cents a ton-mile; and another was boldly requesting an increase to a dollar a ton-mile for mail. Finally, cognizant of the manifest incongruity of the situation, ${ }^{01}$ the Board, on its own initiative, suspended the certificated airlines' low tariffs and ordered a comprehensive cargo rate investigation. ${ }^{02}$

If effective, the inquiry will isolate the factors determinative of rates, shed light on the problem of "joint" costs that are allocable not only to mail carriage but other services also, ${ }^{93}$ and permit the Board to perform more effectively its avowed function of relating rates to costs. ${ }^{98}$ But the consumer has been a direct beneficiary of this vigorous competition offered by the noncertificated airlines to the Railway Express Agency and the established certificated air carriers. The emphasis on control of costs and the improvement of techniques has led to startling rate reductions until today air cargo tariffs are but a fraction of air express rates and closely approach the charges of rail express. ${ }^{95}$

\section{Entry of the Freight Forwarder}

Another phase of the air cargo problem is before the $C A B$ for final action after a five-year delay. It involves the freight or express forwarder, a recognized entity in all forms of surface transportation, ${ }^{\mathrm{t3}}$ who, though not him-

90. Id. at 10 .

91. The foregoing facts were known to the Board and were the subject of violent argument during the proceedings. Id. at 9-10.

92. Investigation of Air Freight Rates, C.A.B. Order E-1016 consolidating all dod:ets (Nov. 20, 1947) ; Petition of Slick Airways, C.A.B. Doc. No. 3170, Order E-916 (Oct. 24,1947 ) (mimeo) (Board suspended the low rates and effected a "freeze" on rate filings by both certificated and non-certificated air carriers); Investigation of cargo rates authorized by Air Freight Forwarder Ass'n, C.A.B. Doc. Nos. 3042, 3132, Orders E-754 and E-853 (Aug. 15, 1947, Oct. 2, 1947).

For a treatment of air cargo rates and rules prior to this action of the Board, see Torgerson, History of Air Freight Tariffs, 15 J. Ars I. 47 (1948).

The latest step in the controversy has been the promulgation of rates by the Board; 16 cents per ton-mile for the first 1000 ton-miles in any one shipment and 13 cents per ton-mile for all ton-miles in excess of 1000 ton-miles in any one shipment. In the opinion of the $\mathrm{CAB}$ the rates under investigation "endanger the sound economic development of air freight" Air Freight Rate Investigation, C.A.B. Doc. No. 1705 et al, Order No. E-1415 (April 21, 1948).

93. See note 160 infra.

94. Id.

95. See note 83 supra.

96. For a history of the express and freight forwarder in railroad and motor carrier 
self a carrier, consolidates small shipments into bulk lots, sharing with the consignor the saving effected by the lower rate schedules applying to bulk shipments. ${ }^{97}$

In 1942, the Board deviously ascertained the supposed intent of Congress and held that a forwarder shipping by air as a common carrier was an "air carrier" within the meaning of the Civil Aeronautics Act, ${ }^{98}$ even though he operated no aircraft, and must therefore obtain a certificate prior to operation. ${ }^{99}$ No certificates have ever been issued, and only the Railway Express Agency has been fortunate enough to obtain even a temporary exemption from the certificate requirement. ${ }^{100}$

Manifestly this situation could no longer continue unnoticed in view of the astounding increase in air cargo. The $C A B$ has ordered the usual investigation into the proper economic controls for forwarders. ${ }^{101}$ There is precedent in other fields of transportation for permitting unrestricted entry, ${ }^{102}$ and this appears to be a logical result even in air transportation, for the freight forwarder is merely a large consignor and cannot precipitate the "destructive" airline competition so feared by the Board. ${ }^{103}$ In view of recognized $\mathrm{CAB}$

transportation, consult Elggren, What Part Shall Freight Fortarders Have in the Development of the Air Freight Industry?, 14 J. AIr. L. 170 (1947); Ahearn, Frcight Forwarders and Common Carriage, 14 I.C.C. PRACT. J. 401 (1947).

97. Typical of a forwarding operation is the following: if each of 10 one-potund packages were shipped separately from Detroit to Chicago, the REA's air express would be $\$ 1$ for each, or a total of $\$ 10$; but, when a forwarder consolidates the ten shipments into one 10-pound package, the total cost is only $\$ 1.32$. Therefore, if a forwarder were to charge $65 \$$ per one-pound package, he would receive $\$ 6.50$ from the 10 individual shippers and obtain a gross profit of $\$ 5.18$. Universal Air Freight Corp., Investigation of Forwarding Activities, 3 C.A.B. 698, 703 (1942).

98. 52 StAT. 977 (1938), 49 U.S.C. § 401 (2) (1940), CAA \& 1 (2) (1938).

99. Railway Express Agency, Inc.-Certificate of Public Convenience and Necessity, 2 C.A.B. 531 (1941). The Board held that the Railway Express Agency was an "air carrier" and thereby required to obtain a certificate prior to operation; but the REA was not entitled to a "grandfather" certificate since that provision [52 STAT. 987 (1938), 49 U.S.C. $\S 481$ (e) (1940), CAA $\S 401$ (e) (1938) ] only pertained to those concerns that physically operated aircraft. By this decision the $C A B$ secured control over forwarders in the air industry without committing itself to a definite stand on the status of the REA; and any attempt by the ICC to extend its jurisdiction over air forwarding because of the railróad parentage of the REA was forestalled. See Elggren, supra note 96, at $196 \mathrm{ct}$ scq.

100. Ibid. Another concern contended it was a shipper, utilizing the services of REA, and not an "air carrier." The Board answered this claim in the negative; refused an exemption similar to that accorded the REA; and issued a cease and desist order. Universal Air Freight Corp.-Investigation of Forwarding Activities, 3 C.A.B. 698 (1942).

101. Re-indirect Air Services in the Transportation of Property, C.A.B. Doc. No. 2540 (Sept. 26, 1946).

102. In the modes of surface and water transportation embraced by the Interstate Commerce Act the instruction is specific: the ICC is directed not to "deny authority to engage in ... the proposed service... [freight forwarding] solely on the ground that such service will be in competition with [that] performed by any other freight forwarder. . . " 56 STAT. 291 (1942) ; 49 U.S.C.A. \$1010(d) (Supp. 1946).

103. The air carriers, fearing competition for their newly instituted Air Cargo, Inc., 
principles in other aspects of its regulatory policy, it seems probable that the proposed control will bar forwarders dominated by a surface carrier, except the Railway Express Agency, which possesses a unique claim if only because of length of operation. ${ }^{104}$ Integration between air and surface forwarders should be facilitated in the interests of efficiency since a sizeable percentage of air shipments must travel part way to the destination by surface carrier. ${ }^{105}$ Recent Board sanction of Air Cargo, Inc., ${ }^{103}$ to coordinate the ground activities of the certificated airlines indicates that forthcoming economic regulations will permit the airlines, certificated and non-certificated, to control air forwarders. ${ }^{107}$

Public interest requires the entry of the air forwarder if a monopoly, or at best a two-firm oligopoly, is not to obtain in air cargo transport. The Railway Express Agency and the certificated airlines' Air Cargo, Inc., offer extensive pickup and coordinated delivery service. A national network of independent freight forwarders is required to supplement the competitive effort exerted by the noncertificated cargo carriers, to perform the promotional function in air transportation that was so ably effected by the freight forwarder in surface transportation, and to pass on the economies of streamlined shipping techniques to the consumer. ${ }^{103}$

\section{Awarding of New Routes}

The development of the "balanced competition" theory has been largely evolved in the route award cases. The authority to award certificates for new service and to extend existing routes provided the $C A B$ with a powerful tool useful both to alter the "grandfather" route pattern in the interests of efficient service-and to affect the competitive structure of the industry so as to approach the avowed goal of strengthening the smaller airlines and of balancing competition.

Initially, the Board subscribed to the notion that air carriers would "emulate" the achievements of other airlines and a stimulus would be provided even if competition were non-existent in a particular area. Although never expressly abandoned, the theory has been eviscerated by the gradual formu-

have been opposing certification of the REA and freight forwarders. See Elggren, siffo note 96 , at 208 .

104. It seems to have been definitely determined that the REA will not be granted an exclusive right. Railway Express Agreements, 4 C.A.B. 157 (1943).

105. Thirty percent of all air express is carried by rail during some part of the journey. Nicholson, supra note 45, at 455.

106. See note 87 sipra.

107. Any monopolistic tendency of such a course is weakened by the ease of entry into freight forwarding, since it requires little capital and is essentially a "service" function.

108. The railroads, much in the manner of the airlines todiy, originally fought the freight forwarder, but the situation has radically altered and the railroads now recoznize the promotional effort supplied by this group of consolidated shippers. Elggren, sstspra note 96 , at 209 . The airlines might do well similarly to relicve thenselves of promotional expense at this stage of their growth. 
lation of the Board's present thesis that administrative fiat alone is not productive of the incentive required to develop an efficient national air system; that only by competition among existing carriers will the public interest be advanced and the economies of technological progress passed on to the consumer. ${ }^{109}$ Maintaining that competition was not deemed mandatory by the Act but was a matter of its administrative discretion dependent on the facts of the particular case, ${ }^{110}$ the $\mathrm{CAB}$ originally permitted existing carriers to compete between major air terminals, first over different intermediate routes, and later, on a point to point basis. And ultimately a prima facie presumption was developed calling for competition on all routes that, in the Board's opinion, exhibit two-carrier traffic potential, unless it be shown that the service of the second airline cannot be integrated into an economically selfsustaining system, or that there would be undue diversion of revenue from existing carriers. ${ }^{111}$ This competition is today said to be justifiable to assure incentive and not dependent on the inability or unwillingness of the existing carrier to furnish the additional service. ${ }^{112}$

As a result of this process of doctrinal evolution, Board action has been uniformly successful in enlarging and modernizing the original "grandfather" route system. Awards have multiplied air mileage, and certification in most instances has been carefully premised on an exhaustive study of a mass of criteria indicating possible national or local need for the particular service. ${ }^{118}$ Further, the $C A B$ has been most active in adjusting the national air map to technological progress in operating performance. Aware of the long range flight potentialities of modern aircraft, the Board has granted permission to

109. It is estimated that the reduction of costs through technology may permit a $30 \%$ cut in passenger rates and a 50\% decrease in cargo rates; reduction of costs may also be achieved by an increase in airline operating efficiency. Barnes, supra note 8, at 441 .

The CAB first realized the importance of this argument in transocean travcl insulated from domestic activity. American Export Airlines, Trans-Atlantic Service, 2 C.A.B. 16, 29 (1940); Additional Latin American Air Service, 6 C.A.B. 857, 863 (1946) ; Northeast Airlines, North Atlantic Routes, 6 C.A.B. 319, 326 (1945).

110. American Export Airlines, Transatlantic Service, 2 C.A.B. 16, 31 (1940).

111. Transcontinental \& W. A., North-South California, 4 C.A.B. 373, 375 (1943). But in the West Coast Case, 6 C.A.B. 961, 970 (1946) the Board states that "the competition will be the incidental result and not the justification for the extension [of service]." But see the treatment of "competition for competition's sake" in Northeast Airlines, Boston Service, 4 C.A.B. 686 (1944) where the phrase is described as "meaningless," since there are many other factors to be considered in a route award. Id. at 690 . In any event, the Board possesses wide authority under the provision providing for "competition to the extent necessary" to prescribe the amount of competition as it will.

112. Transcontinental \& W.A., North-South California, 4 C.A.B. 373, 375 (1943) ; see note 111 supra.

113. Northwest Airlines, Duluth-Twin Cities Operation, 1 C.A.A. 573 (1940) ; Transcontinental \& W.A., North-South California, 4 C.A.B. 254 (1943). For evaluations of the criteria considered determinative, see 1 Aereforts 42 (1947); McMillan, Factors Considered by Civil Aeronautics Board in Certifying Air Carriers, 14 Geo. WASH. L. REv. 611 (1946) ; Paradis, Reference Material Pertaining to the Economic Regulation of Commercial Air Transportation, 7 FED. B. J. 98 (1945); Cromelin, Practice and Procedure in 
consolidate routes and to fly non-stop schedules over the merged segment, ${ }^{114}$ even where this has served to divert revenue from other carriers. Effective action in the supervision of the route pattern, however, has been handicapped by a lack of authority, often requested by the Board of Congress, ${ }^{115}$ to revole route certificates when the public interest dictates.

In direct contrast to its effective record in adapting the route pattern to service requirements is the failure of the Board to use route awards to achieve balanced competition within the structure of the industry. Even as smaller carriers were strengthened by route additions and extensions, the major airlines, members of the oligopoly inherited by the Board, were correspondingly aggrandized; certificates were granted to the larger lines permitting them to round out strong long range domestic routes and to engage in trans-Pacific and trans-Atlantic service, ${ }^{116}$ the latter characterized by the $C A B$ as one of the richest pools of traffic. ${ }^{117}$

In the award of the prime overseas routes to the larger airlines operational efficiency could not have been the determinative factor, since airlines of the second magnitude exhibit the same operating results as the major airlines when both employ the same type aircraft. ${ }^{118}$ Furthermore, because of this Board policy the major airlines have been increased to a size more than large enough to utilize modern and efficient aircraft, whereas the small lines operate systems that in most instances are, without expansion, incapable or efficiently employing long range aircraft. ${ }^{119}$

The impact of technology has augmented the ill effects of the Board's regulatory policy in route awards. The ability to realize the economies of the new aircraft rests mainly with the major air carriers possessing sufficient

New Route Cases Before the C.A.B. 12 J.B. Ass's D. of C. 212 (1945). The Board publishes the results of its many surveys of market data. See CAB, OrIGL: Aitd DESTINation of Airline Traffic (1940); CAB, Ansual Amrline Statistics Dosiestic Carriers; CAB, Airline Trafric Survey (1946); CAB, Ecosoaric Cinaracterustics of Urban PonNts Not Certificated for AIr Service AS of Aprin 1945 (1946).

114. American Airlines Nonstop Services, 7 C.A.B. 13, 16 (1946), American Airlines, Consolidation of Routes, 7 C.A.B. 337 (1946).

115. C.A.B. ANn. Rep. 18 (1942). At present a certificate may only be revoked for an intentional failure to comply with Board directives. See note 136 infra.

116. Northeast Airlines, North Atlantic Routes, 6 C.A.B. 319, 344 (1945) (T.W.A. granted rights; American Airlines to acquire the presently operating American Export Air). Transcontinental airlines, possessing strong financial resources and profitable domestic routes apparently were preferred for this overseas business because of Board concern over prospective severe competition from foreign government-controlled air carriers.

117. Id. at 324. In less lucrative markets, such as the Caribbean, smaller domestic airlines were permitted to share along with the major airlines if the additional service could be integrated into the existing system. Latin American Air Service, 6 C.A.B. 857 (1946) (American Airlines, Braniff, Chicago and Southern, Colonial Airlines, National Airline, Western Air Lines, Eastern Air Lines).

118. See Crane, sitpra note 30 at 507 ; Healy, sipra note 33, at 241.

119. The best operational range for the Constellation type aircraft is 1000 miles and above as compared to 400 miles for the DC-3. 
capital resources ${ }^{120}$ and the long haul routes between important population centers with a traffic potential that will assure adequate load capacities. Increased flying range further strengthens the bargaining position of the larger airlines in that they alone can supply "one plane" and "one carrier" service between the important cities with a minimum of inconvenient connections. As a result, the smaller airlines are further adversely affected by technological progress, since they lose the revenues from the connecting service which they formerly furnished. ${ }^{121}$

The overall result of the Board's policy on route awards has been to preserve the wide disparity in size and strength of the carriers and to retain unscathed the oligopoly condition. ${ }^{122}$ Criticism may well be leveled at the Board on this score, since it had the necessary authority to alter the corporate structure of the industry, and had itself taken the view that a partial solution to the industry's ills lay in strengthening the small lines.

\section{Mergers, Consolidations, and Acquisitions}

Perhaps as a result of the oligopoly long prevailing in the industry, the $\mathrm{CAB}$ was early forced to enunciate its policy on mergers, consolidations, and acquisitions of control of one carrier by another. Board action, consistent with the theory of balanced competition, has been directed at preventing the emergence of a "super-carrier" and at strengthening the competitive position of the small airlines. To this policy must be added the scattered holdings of diverse cases where the decision seems to have been predicated on no other policy than sheer expediency.

The Civil Aeronautics Act provisions on mergers, consolidations, and sales are more complex than these relevant in the award of certificates, for not only must the public interest be considered, but no transaction is to be approved which creates a monopoly and thereby restrains competition or jeopardizes another carrier. ${ }^{123}$ As interpreted by the Board, this permits the approval of arrangements that restrain competition or jeopardize another carrier as long as they do not arise from a monopoly condition. ${ }^{124}$ It then

120. A problem that faces the usual small concern in most lines of endeavor is the excessive cost of raising capital. Figures reveal that firms of less than $\$ 1,000,000$ capitalization must pay $20 \%$ of the stock sales price as a flotation fee, whereas a concern with over $\$ 10,000,000$ capitalization is required to pay a fee of only $9 \%$. Ryan, Problems of Our Domestic Air Transportation, 19 Notre Dans Law. 85, 95 (1943).

121. Typical of such a situation was the position of Western Air, and United Air Lines at Denver. Over $80 \%$ of Western's Los Angeles Traffic originated on or continued along United's route. Therefore, when United, in 1947, was granted entry into Los Angeles, Western was faced with a serious revenue loss.

122. "Big Five" account for over $80 \%$ of revenue passenger miles, $90 \%$ of express pound miles, and $90 \%$ of mail pound miles. FREDERICK, op. cit. supra note 15, at 129 . Consult current issues of C.A.A. Jour. for operating statistics of the certificated airlines, See also Healy, supra note 33, at 241.

123. 52 STAT. 1001 (1938), 49 U.S.C. $\S 488$ (b) (1940), CAA § 408(b) (1938).

124. United Air Lines-Western Air Express, Interchange of Equipment, 1 C.A.A. 
becomes of determinative influence to decide what constitutesa "monopoly". The CAB has chosen to define monopoly in the economic sense of control of the market place and has rejected the antitrust definition of monopoly as "restraint of competition". ${ }^{125}$ Thus, by its findings as to the degree of control present, the Board possesses wide latitude to approve or disapprove agreements endangering competitors. In essence, the Board asserts that there may be restraint of competition without a simultaneous increase in control of the market place, a contention violative of accepted thought on the subject. ${ }^{126}$

The $C A B$ has displayed fertile imagination in creating rationales necessary to achieve its first objective, the prevention of the emergence of a "supercarrier". In denying sanction to a proposed merger which would have constituted the applicant the second largest domestic system, ${ }^{127}$ the Board emphasized the fact that certain routes of the contracting parties served the same population centers. Board criticism was thus not leveled at the size of the proposed organization but at the concentration of control of the particular market place. ${ }^{128}$ In a subsequent proceeding the $C A B$ was confronted with a proposed acquisition of a strong regional carrier by American Airlines, already the largest domestic air carrier. ${ }^{123}$ Since the two airlines did not serve the same territory but merely crossed at one point, additional control of the same market was not involved. Classifying the two systems meeting in the

723,733 (1940). In this case, the Board sanctioned a sleeper interchange agreement between Western and United which eliminated an inconvenient connection at Salt Lakie City. This transaction jeopardized another carrier, but the Board cnunciated a principle to which it has generally adhered: "[i]f . . . competitors are to be prevented from inaugurating improvements in service solely as a protection to a particular air carrier, the development of an adequate air transportation system in this country will be retarded rather than assured." Id. at 731; see Northwest Airlines, Consolidation of Routes, 7 C.A.B. 199 (1946). Where Northwest was permitted to operate directly to Butte, Miontana, from Portland, Oregon, since a saving of 60 minutes in travel time outweighted the ill effects of revenue diversion from United Air Lines at Portland. Id. at 203.

125. United A.L.-Western A.E., Interchange of Equipment, 1 C.A.A. 723, 733 (1940). The Board exhaustively examines the various definitions of monopoly. See also XIason, Mlonopoly in Law and Economics, 47 YaLE L. J. 34 (1937); Hamstra, Watson, Barber, 110nopoly versus Competition in Air Routes under the C.A.A. 12 J. ABs L. 220 (1941). The legal syntax conceives of monopoly as a restraint of competition and the antithesis as free competition; whereas to the economist, monopoly is control of the market and its antithesis is pure competition. In America, the courts have accepted the legal definition of monopoly and, although they keep referring to control of the market, there is little factual consideration of such control. Mason, supra at 34-45.

126. See Mason, supra note 125.

127. Acquisition of Western Air Express by United Air Lines, 1 CA.A. 739 (1940); 11 J. AIR L. 359 (1940). The proposal would have merged United, one of three transcontinental carriers and the second largest of the 17 domestic airlines, with Western, a north-south regional carrier and one of the eight largest airlines.

12S. Id. at 750. The extent of domination of air traffic in the western states if the merger had been approved is graphically portrayed. Id. at 746 ct seq.

129. American Airlines, Inc., Acquisition of Control of Mid-Continent Airlines, 7 C.A.B. 365 (1946). 
one small area as impossible of "integration", 130 the Board thereby displayed a further rationale capable of being employed to forestall the emergence of any carrier dominant either in the control of a specific market, or in the matter of route size.

The second discernible policy relevant to mergers, consolidations and sales has been in furtherance of the declared intention of the $\mathrm{CAB}$ to assist the small airlines. Two techniques are available: the granting of new routes to small airlines, ${ }^{131}$ and the consolidation of a number of the minor carriers.

Failure of the Board route award policy to reduce the great disparity in the size of the carriers has focused attention on the merger technique as a means of equalizing opportunity.

The almost total absence of examples of voluntary mergers or consolidations among small lines designed to provide competition for major air carriers suggests the limited efficacy of voluntary merger as an affirmative instrument of Board policy. ${ }^{132}$ The signal lack of success which has characterized the CAB's exercise of moral suasion to encourage private agreements on beneficial consolidations and sales ${ }^{133}$ has influenced some members to consider the use of some form of coercion as a means of accomplishing desirable mergers of smaller units into transcontinental or multi-regional airlines ${ }^{134}$ which

130. Id. at 373. The $\mathrm{CAB}$ conducted an extensive survey of past passenger exchange between the proposed participants in order to ascertain whether a community of interest existed.

131. See note 36 supra.

132. Typical of desirable combinations is the Northern Consolidated Case, C.A.B. Doc. No. 2209 (May 8, 1947). Permission was granted to six airlines to consolidate in southeastern Alaska; the merged airline will compete with one if not all three of the other airlines in the area, Pacific Northern, Alaska Airlines, and Pan American Airways.

133. Industry commentators are pessimistic about successful consummation of present proposed airline mergers. See 47 Aviation WeEk No. 1, p. 57 (July 7, 1947).

134. For a statement of the position see former Chairman Pogue's "concurring and dissenting" opinion in Northwest Airlines, Chicago-Milwaukee-New York, 6 C.A.B. 217, 243 (1944). Former Chairman Landis was of the same opinion. 47 Avintron WeEK No. 18 , p. 51 (Nov. 3, 1947). It is impossible to forecast what will be the consensus of the new $\mathrm{CAB}$. Another device, in addition to the merger or consolidation, is the interchange agreement whereby airlines agree to permit the aircraft of other carriers to operate over their routes in order to eliminate inconvenient stops. See Westwood and Jennes, Commpulsory Interchange of Aircraft Between Connecting Air Carricrs, $34 \mathrm{~V}_{\mathrm{A}}$. I. REv. 1 (1948). It enables a smaller line to render "one plane" service between major terminals and thereby to compete on a service level with the larger air systems. The technique has never been very popular, the airlines preferring to apply for route extensions rather than join in an interchange arrangement; only three such agreements have been sanctioned. United A. L.-Western A. E., Interchange of Equipment, 1 C.A.A. 723 (1940) (permission granted to exchange sleeper planes; terminated by exigencies of war;) Pan American-Panagra Agreement, C.A.B. Doc. No. 2423 (May 5, 1947) (interchango of equipment at the Canal zone); Transcontinental and Western Air-Delta Air Lines, Interchange of Equipment, C.A.B. Doc. No. 2346, Order E-1084 (Dec. 29, 1947) (mimco) (permission granted to interchange equipment on routes through Cincinnati).

Executives of some airlines have gone on record as favoring a realignment of routes by mergers, purchase and sale, or even an exchange. Smith, sulpra note 4. 
would permit more air systems to have access to approximately equal pools of population, the main determinant of traffic. ${ }^{135}$ Such drastic steps may be necessary in view of the deficiency of the legislative enactment to authorize the Board to revoke certificates when the public interest so requires. Though repeatedly requested by the $C A B,{ }^{120}$ Congress has never seen fit to grant this power, evidently disturbed by a possible loss of confidence on the part of the investing community which desires the certainty of duration characteristic of the certificate. 137

This same solicitude for financial interests has led to random Board decisions, unclassifiable under any consistent policy, which indicate that the Board has occasionally pursued an unfortunate path of expediency in the matter of mergers and sales. This seemingly has been inspired by a dread of the supposedly evil effects of bankruptcy upon the reputation of the air industry and by a desire to eliminate inefficient management. ${ }^{1 \varepsilon s}$ In WesternUnited, Acquisition of Air Carrier Properly, ${ }^{150}$ the Board sanctioned a privately arranged sale by Western to United of the right to operate a specific route and permitted a purchase price that was twice the value of the tangible assets at depreciated cost. This excess amount was paid for the intangible asset, the certificate of public convenience and necessity previously granted by the $\mathrm{CAB}$ to Western at no charge. ${ }^{140}$ By approving this transaction the Board moved counter to an express provision in the Act which states that no proprietary interests are conferred on the holder of a certificate. ${ }^{111}$

135. See Healy, supra note 33, at 237. The Board has stated that any desire to equalize the "size or opportunities of the various air carriers" is subordinate to the consideration of the "public interest" which dictates new routes. Northwest Airlines, Chicago-Milwaukee-New York, 6 C.A.B. 217, 224 (1944).

136. C.A.B. Ann. Rep. 18 (1942). At present a certificate may only be revolied for an intentional failure to comply with Board directives. The President's Air Policy Commission suggest the use of "need" airmail payments to force the airlines to follow the dictates of the Board. Report 111.

For an interesting discussion of the problems raised by the airmail route cancellations of 1934, see Campbell, Procedural Due Process in the Cancellation of Aimail Roste Certificates, 21 WASH. L. REv. 123-55, 206-27 (1946).

137. Time limits have been applied in the approval of "feeder" applieations ( 3 years) and foreign operation (7 years). Local, Feeder, and Pick-up Air Service, 6 C.A.B. 1, 4 (1944) ; Northeast Airlines, North Atlantic Route Case, 6 C.A.B. 319 (1945). "Feeder" airlines may obtain a permanent certificate if the particular operation is successful.

138. See Western A.L.-Acquisition of Inland Air Lines, 4 C.A.B. 654 (1944). This sale was approved in order to eliminate Inland's inefficient management al though there was scant opportunity for integration since only 5.22\% of Inland's traffic traveled over Western's routes. Compare this Board decision with American Airlines, Acquisition of Control of Midi-Continent Airlines, 7 C.A.B. 365 (1946), where the CAB pursued a consistent policy, withholding approval since the carriers exhibited slight integrational characteristics.

139. C.A.B. Doc. No. 2839, Order E-772 (Aug. 25, 1947) (mimeo); Note, 48 Cor L. REv. SS (1948).

140. See WIPRUD, op. cit. supra note 7, at 43.

141. 52 Stat. 987 (1938), 49 U.S.C. $\$ 481$ (j) (1940), CAA $\$ 401(j)(1938)$. Sce 
Equal to the task of selecting plausible rationales, the Board justified its decision on a number of grounds. The majority asserted that private initiative should be encouraged to realign the route pattern, otherwise a "freeze" would ensue; ${ }^{142}$ and that the amount in excess of the value of the tangible assets was "essentially an appraisal of the prospects for successful operation in the future." ${ }^{143}$ Deeming the purchase price to be not unreasonable, the Board called attention to the excellent balance sheet position of the vendee and concluded that United could afford the purchase price even though in excess of the value of tangible assets. ${ }^{144}$

This reference to the financial position of the vendee directs attention to the underlying reason for the decision, the straightened circumstances of the vendor. ${ }^{145}$ Western's profit on the immediate transaction was illusory, since this windfall merely would reduce the operating deficit and therefore reduce future mail payments by the government. ${ }^{146}$ However, approval of this transaction was a condition precedent to a loan by the Reconstruction Finance Corporation to Western, the proceeds of which were urgently required to meet maturing obligations that might well have precipitated reorganization proceedings. ${ }^{147}$ The $\mathrm{CAB}$ by this action has again moved to preserve inefficiency in much the same manner as employed in the "special" mail payments made to airlines in straitened financial circumstances. It might be wise for the Board to review its position in the light of the Civil

Former Chairman Landis' dissent in the Western-United, Acquisition of Air Carrier Property, C.A.B. Doc. No. 2839, Order E-772 at 17 (Aug. 25, 1947).

142. It is a matter of conjecture whether the approval of this sale will facilitate route adjustments or whether it will strengthen the position of the prospective vendor. Further, there is some question as to the desirability of private initiative as a determinant of the route pattern once the industry has been subjected to governmental regulation.

143. Western-United, Acquisition of Air Carrier Property, C.A.B. Doc. No. 2839, Order E-772 at p. 37 (Aug. 25, 1947) (mimeo).

144. Pointing up the obvious makeweight character of this argument is the fact that in a previous proceeding the $C A B$ had refused to certificate a competitor to United on the Seattle-San Francisco route because of a solicitude for United's declining financial position. West Coast Case, 6 C.A.B. 961 (1946). However, competition was subsequently permitted.

Also compare the Board's previous stand that "[t]he reasonableness of the acquisition price may not be judged solely by whether the purchaser can afford to pay that price." National-Caribbean-Atlantic Control Case, 6 C.A.B. 671, 677 (1946).

145. A prior Board decision approving the acquisition by Western of Inland Air Express probably was a contributing factor to Western's present financial difficulty. The $\mathrm{CAB}$ had admitted that its main purpose in sanctioning the sale was to eliminate Inland's inefficient management. Unsuccessfully the dissent had endeavored to remedy the weaknesses in Inland's structure before any approval of the sale. Western A.L. Acquisition of Inland Air Lines, 4 C.A.B. 654, 664 (1944).

146. This is true because Western is in "need" of special financial assistance. Sce in this connection former Chairman Landis' dissent at p. 43 in Western-United, Acquisition of Air Carrier Property, C.A.B. Doc. No. 2839 Order E-772 (Aug. 25, 1947) (mimeo).

147. The $C A B$ must approve all loans made by government agencies to the airlines. 52 Stat. 1003 (1938), 49 U.S.C. $\$ 490$ (1940), CAA $\S 410$ (1938). Greater authority 
Aeronautics Act which provides for assistance, financial and otherwise, to carriers "operating" under "efficient" management.

Other ill effects of such a decision as the Western-United are inevitable. The $\mathrm{CAB}$ openly has approved a sale at a price totally unrelated to the cost of the assets involved ${ }^{148}$ and thus has set a dangerous precedent sanctioning future sales to the highest bidder, ${ }^{149}$ namely the major airlines with the necessary capital. Intangible values have been introduced into the balance sheet and will exercise a profound impact on rates, for the vendee desires a return on the entire investment, comprising both tangible and intangible assets. Since the Board in the case asserted that steps were to be taken to prevent the intangible value from affecting mail rates, passenger rates may well bear the burden. In reality, the $C A B$ has admitted its regulatory inadequacy by permitting a value to be attributed to the certificate, which amount represents a capitalization of expected excess earnings, the fruit of Board ineffciency in restricting the rate of return to the tangible base. ${ }^{1: 3}$

Board philosophy on mergers and sales has been partially successful. Use of these techniques by the major airlines to further increase their size has been somewhat thwarted. However, the use of the power to approve mergers as an affirmative weapon of Board policy has not been explored, perhaps because of a belief on the part of the CAB that the most effective method of reducing the oligopoly and of overcoming the difference in size of the carriers is through the award of new route certificates. With the failure of the route award technique to accomplish the desired results, the Board may have to turn to a program of planned mergers. Pending investigations ${ }^{152}$ provide a springboard for any such approach, but the potential ill effects of makeshift arrangements of expediency suggest great caution in its application.

\section{Rates and Subsidies}

The Board may exercise a direct influence on the operating revenues of the airlines through its control of rates and subsidies. ${ }^{132}$ Airlines are required to file rate schedules with the $C A B,{ }^{153}$ which, in turn, may approve or sus-

over the financial affairs of the airlines has been requested by the Board. C.A.B. Azz:. REP. 21 (1946).

148. The Board has sanctioned other transactions involving smaller sums where the sale price was greater than the value of the tangible assets, holding that the price was "not disproportionate to the values actually attached to the property and business." United A.L., Acquisition of Lamsa, S.A., 4 C.A.B. 409, 413 (1943) ; Acquisition of Marquctte by TWA, 2 C.A.B. 409 (1940) (the Second Marquette case).

149. In fact, Western Air Lines is planning to dispose of its Inland Air section, and the bidding may be spirited. 47 Aviation WeEK No. 9, p. 12 (Sept. 1, 1947).

150. Troxel, Economics of Public Uturties 310 (1946).

151. See note 11 sipra.

152. See generally Highsaw and Burt, Regulation of Rates in Air Transporlation, 7 LA. L. Rev. 1, 1-22, 378-97 (1946).

153. 52 Stat. 992 (193\$), 49 U.S.C. $\$ 483$ (1940), CAA $\$ 403$ (1938). 
pend the proposed rates, or may promulgate a schedule of its own choice. ${ }^{164}$ On the other hand, mail payments, often containing an element of subsidy, are the initial responsibility of the Board and are based on the operating statistics of the particular airline. A most important phase of government assistance to the air transport industry and truly a subsidy is the establishment and maintenance of the navigational and safety aids which comprise the airways. Current indications are that in the near future the airlines may be called upon to pay "use charges" in order to travel these airways. 1 "6

Scant attention has been paid by the Board to the matter of rate regulation; the industry has possessed wide latitude in the promulgation of tariff schedules. Possibly because of the oligopoly, advances and reductions in fares generally have been effected by the simultaneous action of a number of airlines. Other than in special instances of extremely limited consequence, ${ }^{160}$ the Board only once has taken strong affirmative action against the airlines in the matter of rates. During the war the profit position of the air carriers was greatly improved by peak loads and high aircraft utilization, and the Board considered a rate reduction to be appropriate. Although never prosecuted to a conclusion, this proceeding ${ }^{157}$ was successful in its coercive roleand also emphasized the extremity of circumstance required to prompt Board action.

Board regulation of the economic structure of the industry and of the component units has exercised a determinative effect on rates. Because of a policy of restricted entry, the industry has been isolated from a competitive force that might have exercised an important influence on costs and thereby on rates similar to the development that occurred in the case of air cargo transport. ${ }^{158}$ With the extreme importance of variable expenses in the industry, control of costs is essential to lower rates, and Board policy, especially the manner in which airmail subsidies are employed, has rendered the industry blandly unconcerned with cost. ${ }^{159}$ Little pressure has been brought to

154. 52 STAT. 1018, 49 U.S.C. $\$ 642(d)$ and (g) (1940), CAA $\$ 1002(d)$ and (g) (1938). The CAB possesses limited power to fix international rates to the extent necessary to correct discrimination. 52 Stat. 1018 (1938), 49 U.S.C. \$642(f) (1940), CAA $\$ 1002$ (f) (1938). The Board has frequently requested Congress to extend its powers over international rates. C.A.B. ANN. Rep. 14 (1942); id. at 21 (1946).

155. See C.A.A. Report of a Study of Charging for Federal Airways Senuices (Dec. 31, 1946) (report to Congress).

156. E.g., Air Passenger Traffic Discount Investigation, 3 C.A.B. 242 (1942) (airline credit card system) ; Government Travel Discount Tariff Investigation, 6 C.A.B. 825 (1946) (government employee discounts).

157. C.A.B. Doc. No. 850, Order 2164 (Feb. 27, 1943) (airlines ordered to reduco rates $10 \%$; proceeding later dropped after five carriers had complied).

158. See p. 1068 supra.

159. "I believe that we should critically examine the habit and method of subsidizing air carriers. We should evaluate the situation to see if there is not a dulling of incentive, resulting from the method of fixing payments. I fully recognize the current need ... but, we must not get into cost-plus habits in industry. When increased costs do not affect profits, it seems reasonable to presume that most of the incentive toward eff- 
bear on the airlines to attain cost accounting accuracy in the proper allocation of "joint costs" to the respective service of mail, cargo and passenger carriage. ${ }^{160}$ Moreover, on the level of the rates proper, it is imperative that the Board, in addition to evaluating the possible beneficial effects of competition from outside the industry, guard against the incipient development of a rate bureau structure similar to that in existence in the railroad industry. ${ }^{101}$

Airmail payments, commonly referred to as subsidies, have been the subject of serious Board concern, unlike the matter of rates. Much discussion has raged in the industry as to whether the subsidy was being extended to the user of the airmail or to the airlines; but agreement exists that mail payments have not been related to the value of the services rendered. Disparate mail rates have been evolved for carriers in differing financial positions. ${ }^{102}$ Service rates exist for the self-supporting airlines, and a number of formulae are employed to compensate air carriers in "need" of support to finance operating deficits.

In effect, the subsidy payment acts to preserve the status quo and the inefficient. ${ }^{163}$ Employing the subsidy as an affirmative instrument in the expansion of the ill-advised "grandfather" route pattern, the CAB has enabled air carriers to add new routes relatively unhampered by economic considerations. This has permitted the issuance of many certificates to applicants motivated by various non-economic stimuli, prestige factors, and defensive expansion to forestall possible future competition. ${ }^{108}$

Subsidy computations are based on past operating data, with no assurance that previous expenses incurred have been the result of "efficient" management. Occasionally an inadequate "yardstick" is furnished by the business statistics of a competitor whose operating conditions are always distinguishable from those of the carrier under consideration. Since losses usually are

ciency and progress will be lost." Statement of W. Averill Harriman, Secretary of Commerce, to the President's Air Policy Commission, Nov. 26, 1947, 94 Cong. Ree. 448 (Jan. 21, 1948). See also Nicholson, supra note 45 , at 456 et scq.

160. See FREDERICK, op. cit. supra note 15 , at 412 et seq. This problem has long faced the CAB though it has delayed taking definite action. See Burt and Highsaw; supra note 152, et seq. Yet the Board has stated its position on rates to be "The cheapest rates consistent with sound economic principles." North Atlantic Traffic Conference, 6 C.A.B. 845,850 (1946).

161. See Board Member Lee's dissent in the IATA Traffic Conference Resolution, 6 C.A.B. 639,646 et seq. (1946).

162. See Highsaw and Burt, supra note 152 ; Frederick, op. cit. suspo note 15 , at 298 et seq.; Eastern A. L., Mail Rates, 6 C.A.B. 551 (1945) (45\& per ton-mile decreed for the four major airlines-calculated to guarantee a return of $24.57 \%$ on total investment required); National A.L. Mail Rates, 7 C.A.B. 387 (1946) (60\& per ton-mile granted; the $C A B$ stated that service rates should be based on more than the operating experience of one carrier. Id. at 405. The President's Air Policy Commission indorses the continuance of direct Government financial aid. REFOBT 102.

163. Further, the concept of mail rates based on a fair return to invested capital does not take into account the need for equity capital, which is the type of seeurity best suited to air transport, an industry with fluctuating revenues. Harding, Air Tronsforlation Rates, 18 HaRv. Bus. REv. 337, 340 (1940).

164. See Nicholson, supra note 45 , at 454 . 
assumed by the government, the carrier is free to continue operations unworried by the spectre of bankruptcy or reorganization.

An alternative, now practicable because of the Board investigation into cargo rates to isolate rate-determining principles and joint costs, would be to pay the airlines for the value of the service rendered in transporting the mail. ${ }^{165}$ This would be the revenue that the air carrier could obtain by utilizing the space for the carriage of other type cargo. Any additional funds required by an airline to continue operations would be a "real" and recognizable subsidy separated from the mail payment for future Board consideration. ${ }^{166}$ Current $\mathrm{CAB}$ investigations into mail rates and uneconomic route characteristics ${ }^{167}$ may force revision of the present method of airmail payment and produce a new formula calculated to emphasize strict cost control and lower rates.

\section{ConcLusjon}

The main task of the $\mathrm{CAB}$ is to make air transport cost conscious in order that the potential market may be exploited and the consumer benefited. ${ }^{168}$ All phases of Board policy should be so oriented: the paternalistic subsidy system should be drastically revised in order that assistance be given only to those airlines exhibiting managerial efficiency in the control of costs; ${ }^{169}$ new entrants should be considered as a source of competitive pressure on the presently certificated airlines; ${ }^{\mathbf{1 7 0}}$ and the wide disparity in size and strength of the air carriers could be minimized in order that equal access may be had to population pools and to the products of technological progress. ${ }^{171}$

The $C A B$ would seem to have struck upon a reasonable formula in its avowed goal of "balanced competition". A closer approximation of word and deed by the Board should contribute to the development of a national air transport system and secure for the consuming public the same benefits in all fields of air transportation that competition has produced in the field of air cargo.

165. Id. at 456 et seq.

166. The President's Air Policy Commission can see no merit in such an approach at this time, but recommends a study of the cost of airmail service with a view to the future. The Commission's suggested formula for "need" airmail payments is complex, consisting of "standard operating costs of various types of services [to] be developed by the Board" and "kept current with changes in the general price level by frequent adjustments to conform to an industry cost index." REPORT 103.

167. See note 11 supra.

168. The costs of air transport service are extremely high. Consult Crane, supra note 30, at 500 et seq. A feeling exists that Board regulation has lessened the urge of firms to reduce costs, since the CAB usually may be relied on to "legitimize" the higher costs. See Healy, supra note 33, at 242.

169. For an example of $\mathrm{CAB}$ action in dealing with an inefficient carrier, see Colonial Air., Mail Rates, 4 C.A.B. 71, 78 (1942) (In a mail rate case, Board refused to be swayed by Colonial's low return because operating costs were far above those of industry.)

170. See WIPRUd, op. cit. stipra note 7, at 44 .

171. For a discussion of a new development that possibly may improve the competitive position of the small airline, see Rheinstrom, The Aviation Consultant, 14 J. AIR L. 24 (1947). A small carrier may now avail itself of many specialized services (market analysis, engineering research) which were formerly unavailable because of the prohibitive cost. 